\title{
TEN YEARS AFTER THE CRISIS
}

\section{Thoughts on the Reform of Financial Regulation ${ }^{1}$}

\author{
Mária Móra
}

\section{ABSTRACT}

The global crisis of 2008 has radically changed the regulation of the financial mediatory system. The aim of the reforms was to correct the major errors which emerged after the crisis and remedy fundamental deficiencies. This article provides a short overview of the original objectives of political decision makers and regulatory authorities. The specific rules and regulatory initiatives by means of which these objectives were meant to be achieved are examined in each case. Practically, the crisis-induced regulation can be regarded as completed. Currently, the agenda of the competent authorities includes the support of consistent introduction, the elimination of possible contradictions and the fine-tuning of rules. After more than ten years, it is a matter of course that the reality and the achievement of the original goals, as well as their effect on the participants of the financial system, should be examined. The third part of the article deals with this latter topic.

In many respects, the regulatory reform has been successful. In other areas, its effectiveness and practical implementation are questionable. Ultimately, the coordination and simplification of complex regulation, as well as the assurance of its level playing field character are fundamental interests of the wider community, as well.

JEL codes: Go1, G21, G28

Keywords: global financial crisis (GFC), financial regulation, capital, liquidity, supervision, resolution

1 When writing the article, I used my materials prepared for the regulatory annexes to the quarterly reports regularly published on the website of the Hungarian Banking Association (www. bankszovetseg.hu).

2 Mária Móra was the deputy secretary general of the Hungarian Banking Association for 18 years, until 2019, now its Chief Advisor. Email: mora.maria@bankszovetseg.hu. 


\section{INTRODUCTION: ABOUT THE FINANCIAL CRISIS AND THE NEED FOR A COMPREHENSIVE REGULATORY REFORM}

In 2008, the global financial crisis, which was made apparent by the bankruptcy of the Lehman Brothers and later escalated to the real economy, profoundly changed the world; its political, social and economic consequences will stay with us in the long run. Regarding the scale of the crisis, a few figures should be mentioned: The increment loss arising from the crisis is estimated to amount to more than USD 10,000 billion, which was one-sixth of the global GDP in 2008. Only the financial institutions wrote off USD 2000 billion as loss. In 2009, the global GDP shrank in the real sense. As a result of the crisis, unemployment significantly increased in the developed economies. In some southern European countries, it is still very high (Greece: 20\%, Spain: 15\%).

In order to preserve financial stability, the EU Member States adopted packages worth EUR 100 billion to save their banking systems. Germany provided a budget of around EUR 500 billion, Ireland a budget of EUR 485, France a budget of EUR 360 billion, the Netherlands and Sweden a budget of EUR 200 billion respectively, Austria and Spain a budget of EUR 100 billion respectively, while the UK a budget of around GBP 300 billion for institutions in need, in the form of capital increase or state guarantee. In the United States, the Troubled Asset Relief Program provided USD 700 billion in total for the stabilisation of the banking system. (Later, the amount given for the buyout of troubled assets was reduced to USD 475 billion.) In the developed economies, due to bail-out packages, state debt rose to an unprecedented level. Although it has decreased since then, it is still well above the pre-crisis level.

When the financial crisis broke out, different analyses largely agreed on the reasons: the factors resulting in the crisis included lax monetary policy and continuously growing real estate prices (bubbles), supervision that was not strict enough, long-lasting abundant liquidity, too high leverage, uncontrollable and non-transparent financial innovations, the weaknesses of the originate to distribute model, a high level of maturity transformation and unfounded positive rating of securitised products, as well as the excessive and badly structured compensation practise. According to ex-post evaluations, the main reason for the crisis was global imbalance (the asymmetry in the foreign trade between the USA and China). In addition, the inappropriate regulatory environment, banking deregulation, the evolvement of a shadow banking system, the bank behaviour and banking 
culture evolving under the influence of bad incentives were decisive in the development of the crisis. On the other hand, the procyclical character of regulation - the capital adequacy requirement constricting lending activity at system-level contributed to the deepening of the crisis. In the light of the above, it is clear that the need for the profound reform of financial regulation showed itself with elemental force.

In connection with regulatory reforms, the following general political intentions and expectations were expressed:

By means of and as a result of the reforms

1) the stability and resistance of the individual banks has to be increased,

2) the stability of the financial system has to be consolidated ${ }^{4}$,

3) the exposure and vulnerability of taxpayers, as well as the possibility of using taxpayers' money, should be reduced,

4) trust in the financial system has to be restored.

In accordance with the expectation above, the following regulatory objectives emerged:

1) The capital and liquidity of banks has to be reinforced, leverage has to be reduced and the risk management conducted by banks has to be strengthened.

2) The macroprudential approach should be promoted, the procyclical character of regulation has to be weakened and the danger of the contagion effect has to be reduced. The security of derivative markets should be enhanced, and the shadow banking system should be reformed.

3) The problem "too big to fail" (TBTF) should be tackled.

4) The whole regulatory package aimed to restore confidence, but the importance of the establishment of an appropriate incentive and compensation system was expressed separately, as well. Moreover, on the part of the society, the demand for the criminal liability of guilty bankers was strong, as well.

Immediately after the crisis, the reinforcement of prudential supervision, as well as the establishment of supervisory cooperation and consolidated supervision was considered to be priorities among the regulatory objectives. Learning from the negative experience gained during banking crises, special attention was paid

4 As far as the regulatory objectives are concerned, the assurance of the competitiveness of financial markets was put aside for a longer time after the crisis. 
to setting the rules for administrative/supervisory cooperation in stress situations as soon as possible. The regulation of credit rating agencies, the reinforcement of their supervision, the disclosure of ratings and, in general, the increase of transparency and the improvement of evaluation standards were also prioritised.

The political decision makers (the G2o leaders) considered the need for global, level playing field regulation as a regulatory principle and were committed to the harmonised, timely consistent and competition-neutral introduction of jointly elaborated and approved rules. The initial demands included prioritising the self-regulatory character and the avoidance of excessive regulatory reactions, but these considerations were forgotten soon.

Part II of the article reviews from a bird's-eye view the actual rules the regulatory authorities adopted following the crisis. The article does not aim to provide a detailed overview of the content of the rules, but it rather attempts to present the regulatory instruments which were used for the management or solution the faults and deficiencies detected during the crisis. ${ }^{5}$ Part III evaluates the established set of rules.

\section{FINANCIAL REGULATION ESTABLISHED AFTER THE CRISIS}

\subsection{Global regulation}

\subsubsection{Prioritising the macroprudential approach}

Following the crisis, the most important change in the approach to regulation was prioritising the macroprudential perspective. "Some international financial institutions and researchers dealing with the subject became aware of the existence and significance of macroprudential risks only after the major financial crises of the late 199os, the Asian and the Russian crises and the crash of Long Term Capital Management as a result of the latter. ... The shock caused by the GFC (global financial crisis) made each actor realise the main reasons for macroprudential risks are the financial crises." The large number of bankruptcies, contagion phenomena, herd behaviour, beyond the situation of individual banks, the concurrent fall of asset

5 Despite its schematic character, the overview does not aim to be exhaustive; consequently, it does not deal with the regulation of shadow banking activity or that of credit rating agencies, the reduction of excessive dependency on credit rating agencies, the changes in accounting standards, different data collection efforts and the establishment of global registry systems.

The article and the bibliography do not include any references to specific rules, owing to their high number. The rules can be found on the websites of the competent authorities:www.bis.org, www.fsb.org, www.ec.europa.eu, www.ecb.europa.eu, etc.

6 MÉRő (2017) deals with prioritising macroprudential regulation in detail. 
prices drew attention to the importance of the macroprudential regulation of the financial system and the importance of its supervision. Previously, the main focus was on the stability of individual institutions.? (About the comparison of the two different approaches, see: Table 1.)

\section{Table 1}

The comparison of the macro- and microprudential approaches

\begin{tabular}{|c|c|c|}
\hline & Macroprudential & Microprudential \\
\hline Interim objective & $\begin{array}{l}\text { Reducing the problems } \\
\text { affecting the entire financial } \\
\text { system }\end{array}$ & $\begin{array}{l}\text { Reducing the problems } \\
\text { affecting individual } \\
\text { institutions }\end{array}$ \\
\hline Final objective & $\begin{array}{l}\text { Avoidance of losses } \\
\text { in the economic } \\
\text { performance (gdp) }\end{array}$ & $\begin{array}{l}\text { protection of the consumer } \\
\text { (investor/depositor) }\end{array}$ \\
\hline Nature of the risk & (partly) endogenous & Exogenous \\
\hline $\begin{array}{l}\text { Correlations between } \\
\text { institutions, the exposure } \\
\text { of multiple institutions } \\
\text { to the same risks }\end{array}$ & Important & Insignificant \\
\hline $\begin{array}{l}\text { Calibration } \\
\text { of prudential controls }\end{array}$ & $\begin{array}{l}\text { A top-down approach } \\
\text { focusing on the entire system }\end{array}$ & $\begin{array}{l}\text { A bottom-up approach } \\
\text { focusing on specific risks }\end{array}$ \\
\hline
\end{tabular}

Source: Mérö (2017) quotes Borio (2003).

The macroprudential approach has two determining features: (i) it examines the financial system in its entirety so as to limit the macroeconomic costs of crises; and (ii) it considers aggregate risk as the result of the common behaviour of financial institutions, in order words, as endogenous.

The two dimensions of the macroprudential approach:

- It examines how a risk spreads throughout the financial system at a given time (cross-sectoral dimension). (It examines the same risks arising concurrently.)

- Examining how the aggregate risk changes over time (time dimension). ${ }^{8}$

The establishment of the institutional system supporting the practical implementation of the macroprudential approach was an important element of the

7 According to Dӧмӧтӧв et al. (2016): "In general, it can be stated that the current reforms are not aimed at the individual risk-taking of institutions, but rather intend to mitigate system-level risks arising from network externalities.

8 See: Borio in the CEPR Press Studies 1.3 (2015) 
macroprudential change. Earlier, in April 2009, expanding the Financial Stability Forum, a weak consultation body regarding its mandate and the number of participating countries and international institutions, the $\mathrm{G} 7$ countries set up the Financial Stability Board (FSB), which is responsible for giving effect to the macroprudential approach at global level. The appropriate bodies were established at EU as well as at national level, and the authorities in charge of macroprudence were appointed.

The appearance of macroprudential elements in the Basel III regulation can be considered as one of the most important novelties compared to the Basel II Accord. ${ }^{9}$ The capital add-on requirements prescribed for institutions representing systemic risks at global or national level, the compulsory liquidity indicators, the applicability of the systemic risk buffer as well as the capital add-on that can be prescribed for excessive risks of the same character in the framework of the Supervisory Review and Evaluation Process (SREP) serve the management of the same risks arising concurrently. The introductions of the institution of resolution and - in a certain sense - the regulation of the renewed trading book also belong here. The capital conservation buffer and the countercyclical capital buffer protect against the temporal build-up of risks, but the restriction of leverage can also be classified into this category. The macroprudential character is becoming more visible in stress tests ordered by supervisory authorities, as well.

Globally, there are no rules regarding this approach, but even LTV (Loan-to-Value) and DTI (Debt-to-Income) indicators can be used for limiting macroprudential risks within national competence.

\subsubsection{Strengthening the capital position and liquidity of the banking system - the Basel III regulation}

\subsubsection{Basel III Regulation 2010 - 2017}

As part of the global initiative accepted by the leaders of the G2O countries to reinforce the regulation of the financial system, the Basel Committee on Banking Supervision (BCBS) published its consultation documents on the reinforcement of the total capital of the banking sector and the regulation of liquidity already in December 2009. The final version of the regulation was published a year later.

The new set of rules:

9 MÉRő (2017) draws attention to the fact that although the term macroprudential approach was widely used by the senior executives and researchers of the BIS at the time of setting up the Basel II regulation (playing a pioneering role in recognising and raising awareness of the importance of this aspect), the Basel Committee on Banking Supervision did not strive to enforce the macroprudential approach in the course of the establishment of Basel II. 
- It improved the quality, consistency and transparency of the capital in order to increase the loss-absorbing capacity of internationally active banks in case of going concern as well as gone concern. ${ }^{10}$ In addition to the improvement of the quality of primary capital items, other elements of capital structure were harmonised. In order to assess the combined impact of the measures, the proposal about the level and quality of the capital was made in view of a comprehensive impact assessment conducted in the first half of 2010 and the capital requirement for banks was significantly raised compared to the previous level. (Table 2 shows the regulations on capital requirements.)

- Global minimum liquidity standards were introduced for internationally active banks. ${ }^{11}$ The liquidity cover ratio (LCR) can support short-term liquidity, while the net stable funding ratio (NSFR) can support long-term liquidity. The LCR correlates the high-quality liquid assets with the net cash outflow calculated for a period of 30 days, while the NSFR correlates the stable available resources with the stable needed resources. In order to support the Authorities, the BCBS also developed a joint toolkit for liquidity measurement and monitoring. They intended to add an element to the regulation for examining intraday liquidity, but in the end, it was omitted from the set of rules. Furthermore, it was emphasised that the individual national authorities had the right to apply further indicators and regulations beyond the proposed toolkit. In addition to prescribing the compulsory indicators, the BCBS made the requirements for liquidity management stricter in different guides.

- To complement the Basel II risk-based regulation, the leverage ratio was introducing to prevent the build-up of too high leverage in the banking system. The indicator also protects against model risks and measurement errors and prevents the excessive spread of financial innovations with low capital requirements (low risk-weighted financial innovations) which are risky in reality. (For the sake of comparability, the detailed rules on the ratio, including accounting differences were internationally harmonised).

- New capital reserves were introduced to set off the cyclical operation of the economy. Such reserves are built up in good times and used in case of stress.

10 By limiting the instruments which could be set off against capital, the loss-absorbing capacity of capital was guaranteed.

11 Prior to the crisis, there was no international regulation applying to liquidity. The only expectation was that banks had to have risk-taking and risk management policies and procedures for liquidity management. The requirement of holding excess liquidity that cannot be used in need was considered to be a dysfunctional regulation. In the framework of the SREP, authorities were allowed to prescribe capital requirements to ensure liquidity, but this possibility was strongly contended by the banks. 
Capital conversation buffer is built up in good economic times from retained earnings. In the case of excessively fast increase in lending, the build-up of countercyclical capital buffer is ordered for loans provided in certain jurisdictions. The competent authority shall announce its use one year in advance. (As opposed to the loss-based model, the Committee supported the introduction of the forward-looking creation of provisions based on the expected loss.)

- The circle of risks to which capital was assigned was extended. In addition to the reform of the capital requirements for the trading book and securitisation announced in July 2009 (Basel 2.5), the capital requirement for the counterparty risk of derivative, repo and securitisation-funding transactions was confirmed.

When the measurements were communicated, the BCBS also announced that they intended to encourage the clearing of OTC derivatives through central clearing counterparties.

The new rules had to be introduced gradually (see: Table 3 ) from 2013, taking into account the appropriate transitional measures and the exemptions appertaining to previous instruments (grandfathering).

Table 2

The rules of the Basel III regulation on capital

\begin{tabular}{lccc}
\hline \multicolumn{3}{c}{ Capital requirements and reserves (in percentage) } \\
\hline \multicolumn{1}{c}{$\begin{array}{c}\text { Common stocks } \\
\text { (after deductions) }\end{array}$} & $\begin{array}{c}\text { Basic } \\
\text { capital items }\end{array}$ & Total capital \\
$\begin{array}{l}\text { Minimum } \\
\text { Capital conservation } \\
\text { buffer }\end{array}$ & 4.5 & 6.0 & 8.0 \\
$\begin{array}{l}\text { Minimum+ capital } \\
\text { conservation buffer }\end{array}$ & 7.0 & 8.5 & 10.5 \\
$\begin{array}{l}\text { Countercyclical } \\
\text { buffer (band }\end{array}$ & $0-2.5$ & & \\
\hline
\end{tabular}

Note: ${ }^{\star}$ Common stock or other capital item bearing the total loss

Source: BIS 
Table 3

The gradual introduction of the Basel III rules in percentage ${ }^{\star}$

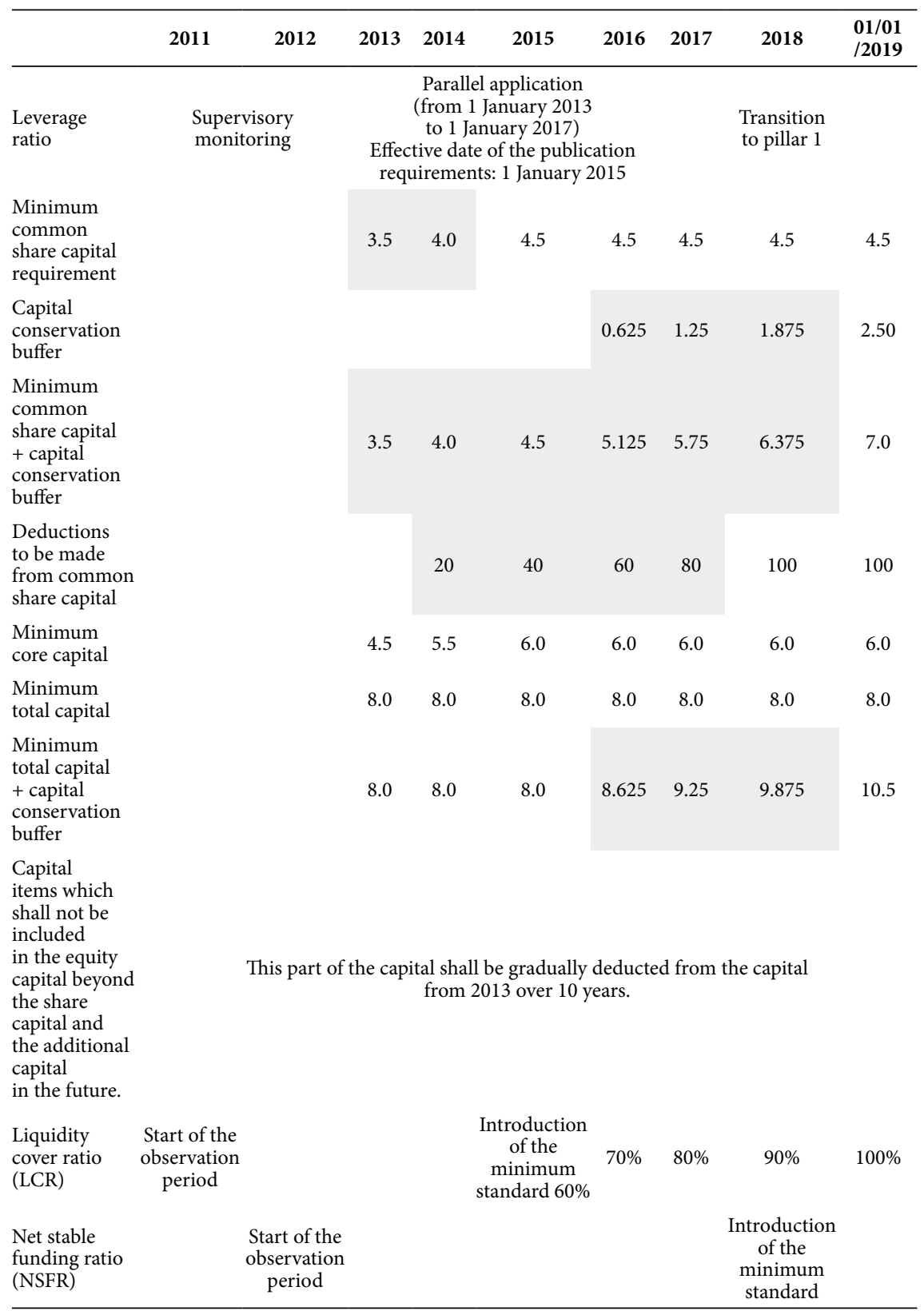

Note: ${ }^{\star}$ Effective date (shading indicates the transitory period). Each date starts as of 1 January. Source: BIS 
In the long period of entering into force, in the light of the experience gained during application and the results of different impact assessments, in addition to finetuning the rules, the Committee was continuously working on finalising Basel III, conducting several consultations on various elements of the set of rules. Already in 2012, a working group was set up to review the capital regulation frameworks established by the Basel Regulations and examine how the undue complexity of the rules could be decreased and how the comparability of the results could be improved. As a result of the work, the BCBS published its discussion paper entitled "Regulatory frameworks: balance between risk sensitivity, simplicity and comparability" (BCBS 2013). Based on this, the Committee looked in particular at the approximation of risk weighting practices, the review of the standard approach, the parameters and assumptions of approaches based on the internal model and the decrease of the variation of the calculated capital requirement.

Following a long-lasting and turbulent consultation process, significantly later than intended, the finalised version of Basel III, which is often referred to as Basel IV in the lingo due to the radical changes compared to the original regulation, was published in December 2017. ${ }^{12}$ (The BCBS consistently insisted on the terminology "finalisation of the Basel III regulation").

The adopted package included the following elements:

- the revised standardised approach of credit risk, which improves the reliability of the current approach and risk-sensitivity;

- the revised internal rating-based (IRB) approach, which limits the use of more developed model approaches. The adopted changes reduce the complexity of the regulatory frameworks, improve comparability and decrease the excessive variability of credit risk capital requirements. In the case of certain exposure categories, the IRB approach cannot be used anymore; model parameter limits shall be applied for some exposure categories; the specification of parameter estimates has become more accurate;

- the revised credit valuation adjustment (CVA) frameworks;

- the revised standardised approach for assessing operational risk, which is to replace the measurement approaches allowed by the Basel II regulation

12 The regulation could not get through in 2016, as the regulatory capital requirement of banks calculating their capital requirement with the internal model would have considerably increased owing to the "bad" calibration elaborated by the BCBS and the introduction of the aggregate output limit. The Canadian, European and Japanese banking association wrote a joint letter to the president of the BCBS, arguing for the use of the model. The changes on the agenda had a particularly negative effect on the European banks, therefore the Commissioner responsible of the European Commission even publicly spoke about the possibility of the rejection of the European introduction. 
(the basic, existing standardised approach and the advanced measurement approach (AMA));

- the measurement of the revised leverage ratio and the prescription of leverage buffer for global banks posing system risks (Global systemically important banks (G-SIBs);

- the introduction of an aggregate output limit (output floor) that ensures that the share of risk weighted assets calculated on the basis of the internal model cannot be lower than $72.5 \%$ of the RWA calculated with the Basel III standardised approach.

Allowing a long lead-time, the new rules are to be applied as of 2022. The value of the output floor shall increase from 50\% in 2022 to $72.5 \%$ only as of 1 January 2027 by increasing 5 percentage points each year. ${ }^{13}$

The Committee also postponed the deadline for the introduction of the fundamental review of trading book (FRTB) from 2019 to 1 January 2022. In the case of credit, market and operational risks, the revised frameworks shall be applied as of 2022 .

\subsubsection{The trading book regulation}

Although the determination of the market risk capital requirement (the trading book regulation) is part of the first pillar of the Basel II regulation, the relevant proposals were separated from other elements of the reform package after the crisis, regarding time as well as the consultation processes. The regulation called Basel 2.5, which reacted quickly to negative market phenomena, preceded Basel III by half a year. The Basel 2.5 regulation significantly raised the capital requirements for trading activity and securitisation, however, it still did not revise the frameworks in a comprehensive manner.

The first time when the BCBS started a consultation about the fundamental review of the capital requirements of the trading book (FRTB) was in May 2012. The proposal set up new frameworks for the regulation of market risk management, tightening the capital requirement of the trading book with several specific measures. Following a multi-stage consultation, the Committee announced the version of FRTB that was meant to be the final in January 2016. The comprehensive review, inter alia, dealt with the limits of classification in banking-books and the trading book; the internal model approach; the confirmation of the adoption

13 The effect of the output floor is different in the individual EU states. First, it may become effective in Belgium, Denmark, the Netherlands and Sweden, while it will affect Italy and France only later. The new rules will not limit US banks at all, as there is a $100 \%$ limit in accordance with the Dodd-Frank Act (Sironi, 2018). 
procedure of the model, the more prudent treatment of portfolio diversification and, as a new element, it included market illiquidity risk. The revised standardised approach was suitable for being an exit possibility and a lower limit for methods based on the internal model, enabling the consistency and comparability of market risk reports between banks and jurisdictions. According to the original agreement, this set of rules should have been applied as of 1 January 2019.

Mainly because of the significantly increased capital requirement, the adopted regulation was severely criticised. The related arguments did not settle. Consequently, based on new consultations and the impact assessment conducted on the figures from December 2017, the Committee modified the regulation again.

Compared to the proposal published in January 2016, the new FRTB published in January 2019 included the following changes:

- simplified standardised approach for small bank with a non-complex trading portfolio,

- clarification on the scope of exposures that are subject to market risk capital requirements,

- refined standardised approach treatments of foreign exchange risk and index instruments,

- revised standardised approach risk weights applicable to general interest rate risk, foreign exchange and certain exposures subject to credit spread risk,

- review of the assessment process that determines whether a bank's internal risk management models appropriately reflect the risks of individual trading desks,

- review of the requirements for the identification of risk factors that are eligible for internal modelling.

The revised standards are complemented by a brief explanatory note by the Committee, which describes the change of regulatory frameworks ignoring technical details.

According to the parallel quantitative impact assessment, the new rules raise the market risk capital requirement by $22 \%$ on average compared to Basel 2.5 . At the same time, the version published in January 2016 would have resulted in a capital requirement increase of around $40 \%$.

\subsubsection{Related rules}

Due to the distressing performance during the crisis, the review of the securitisation frameworks was put on the agenda, as well. The aim of the comprehensive review was to make the capital requirement of securitisation more prudent and 
the more risk sensitive, reduce mechanical dependence on external rating agencies and mitigate the cliff effect manifest in the capital requirement.

The review of the securitisation frameworks is part of the Basel III package in a broader sense. In this respect, the BCBS made its first proposal in December 2012, while it published the final version of the regulation in 2016. First, the Committee defined the criteria of the simple, transparent and comparable (STC) securitisation, and then it specified the capital requirements of such exposures. The standard finalised in 2016 prescribes the fulfilment of additional criteria for the preferential treatment of STC exposures. In the course of the consultation process, the Committee decreased the lower limit of the risk weight of STC securitised receivables from $15 \%$ to $10 \%$.

The regulation of the Interest Rate Risk in the Banking Book (IRRBB) is part of SREP in the second pillar of the Basel II regulation. In April 2016, as an additional element of the reforms, the Committee issued its standard on the Interest Rate Risk in the Banking Book, which is the revised and updated version of the document on the same topic published in 2004. According to the supervisory regulation on the identification, measurement, monitoring and treatment of the IRRBB, the IRRBB still belongs to the second pillar. ${ }^{14}$ The new standard provides more detailed guidance regarding the expectations related to the IRRBB treatment process (shocks, stress scenarios, model terms). A reformed, more risk-sensitive standardised approach was introduced, reinforced disclosure requirements were specified, and a narrower threshold was set for the banks which fail to fulfil the regulations on interest rate risks.

The reform of the market of OTC derivatives is also part of the Basel III package in a broader sense. The package includes the regulation of the management of risks to Central Counterparties (CCPs) and the capital requirement for these risks, as well as the rules on trade repositories.

In order to reinforce financial infrastructures, the FSB prepares a status report on the progress of the reform of the OTC derivative markets every six months. In addition, an expert report was made on data provision related to the trade of OTC derivatives and the cross-border introduction of the relevant rules was also examined.

At the same time, the rules on the resolution of the Central Counterparties are part of the crisis management regulation to be discussed below.

14 As an alternative solution, it was suggested that the capital requirement for the IRRBB should be in the first pillar, but in the end, the idea was rejected. 


\subsubsection{Tackling the too big to fail problem}

Institutions which are too big to fail (TBTF) pose increased risk for the whole financial system, as their possible bankruptcy would have unforeseeable consequences. Therefore, they can usually rely on bailout by the state, which involves significant moral risk. On the other hand, in the course of the globalisation of the financial system, gigantic institutions were born. Their balance sheet total was close to or even exceeded the GDP of the nation states where the given banks or groups were registered. In the light of this, it may occur that the given nation state would not even be able to manage the bankruptcy of such "too big to save" institutions. Therefore, from the point of view of the regulator, the prevention of the possible fall of systemically important financial institutions, as well as the proper and organised management of their bankruptcy, if they go bankrupt despite the preventive measures, are top priorities. Limiting the size and scope of activity of the institutions and the prevention of their further growth were also mentioned as regulatory objectives.

\subsubsection{The regulation of systemically important financial institutions (SIFIs)}

The regulatory authorities examined directly after the crisis whether, in the case of systemically important financial institutions the introduction of additional capital, liquidity requirements or other supervisory rules was needed in order to decrease the externalities caused by the institutions.

One of the directions of the TBTF regulation was the identification of systematically important financial institutions (SIFIs) and the determination of their additional capital requirement. ${ }^{15}$

The regulation adopted by the BCBS in 2011 uses an indicator-based measurement system for judging the importance of G-SIB banks regarding systemic risks. The system takes into consideration the activity, size, mutual dependence, substitutability and complexity of the institutions among jurisdictions with the same weight $(20 \%)$. Within these categories, special indicators with special weights were used for identification. Based on the above-mentioned criteria, the Committee divided G-SIB banks into five groups, prescribing a capital add-on requirement of $1 \%, 1.5 \%, 2 \%$ and $2.5 \%$ per group for the institutions belonging

15 The terms "institutions posing systemic risks", "systemically important financial institutions" and systemic institutions all occur in domestic literature, therefore I use them with the same meaning. 
to the individual groups. ${ }^{16,17}$ Currently, the fifth group with a capital add-on requirement of $3.5 \%$ does not include any banks. By using it, the Committee aims to prevent the further growth of the banks. The additional capital requirement shall be fulfilled at group level by common equity tierı. By prescribing capital add-on - higher loss-absorbing capacity -, the likelihood of the bankruptcy of the G-SIB banks is meant to be reduced. At the same time, it should be emphasised that classification is not based on the likelihood of bankruptcy, but on the expected impact of it. In other words, it seeks to reflect the impact of a possible bankruptcy on the stability of the financial system.

The identification and classification of G-SIB banks and insurance companies is conducted by the FSB, which is primarily in charge of addressing the TBTF problem, on an annual basis and the results are published on the FSB's website. G-SIB banks had to introduce the capital add-on requirement in 2016, while they have had to fully comply with it since 1 January 2019. Amended disclosure requirements apply to the G-SIB banks. ${ }^{18}$

In 2013, by changing a special indicator, the BCBS adjusted the system and decided to review the identification methodology of G-SIB banks every three years. The review ensures that despite changes, the methodology complies with the original objectives and new dimensions can be introduced to filter out unforeseen systemic risks. During the revision of the regulation completed in 2018, the fundamental structure of the G-SIB regulatory frameworks was consolidated again. One of the minor changes was the inclusion of the affiliates of insurance companies in the scope of consolidation.

In addition to holding higher capital, G-SIB banks also had to comply with the TLAC rules and fulfil the resolvability requirements. ${ }^{19}$ (See below!) Moreover, they had to meet enhanced supervisory expectations regarding risk management, the aggregation of risk data, risk policy and internal auditing.

16 In exceptional cases, supervisory assessment can override classification based on indicators.

17 First, the Committee examined 73 internationally active banking groups. 29 of them were found to be G-SIB institutions. In the course of the annual identifications, the circle and number of banks (banking groups) defined as G-SIBs showed only moderate change from one year to another. The G-SIB list published in November 2018 also included 29 banks: 17 of them belonged to the group with a capital add-on requirement of $1 \%, 8$ to the $1.5 \%$ group, 3 to the $2 \%$ group and only one bank (JPMorgan Chase) was in the $2.5 \%$ group.

18 The banks with an exposure exceeding EUR 200 billion (exposure refers to the exposures considered when calculating the leverage ratio) (75 institutions) and the banks classified into the G-SIB category in the previous year shall publish the indicator values on which the classification is based.

19 As of 1 January 2022, the leverage buffer requirement shall come into force, as well. 
In 2012, the BCBS also elaborated the management frameworks of domestic systemically important banks (D-SIBs). The regulation ensures appropriate national discretion, taking into account the structural characteristics of individual jurisdictions.

\subsubsection{The establishment of the crisis management frameworks of banks}

The Financial Stability Board in close collaboration with the Basel Committee on Banking Supervision developed the global principles of the crisis management of cross-border banking groups. The aim of the work was to support the individual national authorities to implement reforms in the field of crisis management and promote the convergence of crisis management practices, better cooperation of home and host authorities, which is a prerequisite for effective international crisis management. Ultimately, the regulatory authorities wanted to find out how bank failures, which occur despite stabilisation measures, can be treated without risking the security of the financial system and using the taxpayers' money.

The establishment of comprehensive international crisis management frameworks for global institutions was based on the FSB document entitled "Key Attributes of Effective Resolution Regimes for Financial Institutions" published in October 2011 and updated in 2014, which is often referred to in international slang as "Key Attributes".

According to the document, an effective crisis management system, inter alia:

- ensures the continuous availability of systemically important financial services, payment and clearing functions,

- enables the protection and quick reimbursement of insured depositors and investors,

- considers the hierarchy of claims when sharing the loss between the owners and the creditors,

- does not spend any public funds,

- avoids unnecessary impairment loss, tries to minimise resolution costs,

- is fast, transparent and as predictable as possible (clarity of legal and procedural rules)

- provides legal authorisation for cooperation, the exchange of information and coordination with domestic and the relevant foreign resolution authorities prior to and during resolution,

- enables unviable companies to leave the market in an orderly manner,

- strengthens the market principle and promotes market-based solutions due to its credibility. 
The FSB regulated the resolution of G-SIB banks. The rules adopted by the individual jurisdictions shall at least apply to these institutions, as well. In accordance with the regulation, each jurisdiction shall set up a resolution authority with appropriate authorisation and powers. The resolution authority shall be authorised to conclude contracts with other resolution authorities and carry out "early intervention". Prior to the start of resolution, the authority shall take a decision on the resolvability of the bankrupt institution. In order to improve resolvability, the authority shall be authorised to change the business practice and the organisational structure. Resolution authorities shall have an extensive resolution toolkit. (For example, the toolkit includes the replacement of the senior management; the appointment of a resolution administrator ; the operation of the company, the conclusion and termination of contracts, buying and selling assets; the provision of basic services; superseding shareholders' rights; the transfer of receivables and liabilities to a third party; the establishment of a temporary bridge organisation for carrying out the fundamental and viable activities; the establishment of a separate asset-management company; the use of bail-in; the suspension of the performance of certain contracts; the application of payment moratorium; granting orderly resolution.) In the course of resolution, it is necessary to take into account the ranking of the creditors by applying the principle "no creditor (shall come) worse off" than in the case of liquidation. The procedure enables exemption from disclosure requirements. The jurisdictions shall establish rules and practices regarding recovery and resolution plans. The resolution authorities shall be obliged to regularly review and maintain the resolution plans. In order to facilitate resolution, the jurisdictions shall have a resolution fund (and/ or deposit guarantee fund) financed from private sources (from the payments of banks).

In the case of cross-border groups, cooperation with the authorities is crucial regarding the success of resolution, therefore a Crisis Management Group (CMG) shall be formed from the resolution authorities of the home country and the important host countries.

In the regulation of resolution, one of the most important new elements is the introduction of the bail-in tool, a debt write-off tool. As opposed to bail-out (the rescue of institutions by the state), the point of bail-in is to involve shareholders and the uninsured creditors in resolution by write-off and the restructuring of obligations. The total loss absorbing capacity (TLAC) requirements (requirements on capital and the sources available in the course of resolution) ensure that the individual institutions have enough instruments for the resolution. The regulation details the types of obligations which can be considered for the fulfilment of the minimum requirement (e.g. by issue date, maturity date) and itemises the external sources which cannot be considered when calculating the TLAC. 
As of January 2019, G-SIB banks shall hold TLAC instruments which constitute at least $16 \%$ of the risk-weighted assets (as of 2022: $18 \%$ ). The minimum level of TLAC leverage shall be $6 \%$ (as of 2022: 6.75\%). The distribution of the instruments within the group is regulated by the internal TLAC rules.

Bearing in mind the avoidance of the contagion effect, the BCBS also took a decision on the prudential management of the asset-side TLAC instruments of banks (issued by other banks).

The FSB facilitated the smooth implementation of resolutions by providing several guidelines, including guidelines on resolution planning for G-SIFIs, cooperating during cross-border resolution, information sharing between authorities and by laying down the principles of temporary financing supporting resolution, as well as the frameworks for contracts helping continuous operation during resolution.

\subsubsection{Structural reform: limiting the size and activity of institutions}

After the crisis, it was generally thought that the bank failures had been primarily caused by prioritising trading activity and the enormous losses. In view of the above, the different structural reform proposals intended to defend the traditional deposit-taking and payment service activities of banks from the harmful effects of money-market volatility. However, expert examinations did not unequivocally support the rationality of the proposals about the separation of commercial and investment banking activities; did not prove the advantages in the field of efficiency which would affect the whole financial system..$^{20,21}$ Although structural regulation may reduce system risk in several aspects, it may also contribute to the fragmentation of banking markets along national borders.

On large financial markets, regulations on the separation of activities were born relatively early (USA: Volcker rule 2013, UK: Vicker ring-fencing 2012), therefore no relevant rules were adopted at global level. Based on the proposal by the Liikanen Committee, a draft entitled "Decree on structural measures improving the security of the credit institutions of the European Union" was on the agenda in the European Union for a long time, but partly owing to the strong resistance of the banking sector, it could not get accepted. ${ }^{22}$ Finally, the European Commission

20 E.g. see: BIS (2013), and Viñals et al. (2013)

21 According to GoodHaRT, in spite of being widespread, the theory according to which an investment bank can be liquidated at lower social cost than a retail bank is wrong. CEPR Press (2015) point 1.6.

22 The European Banking Federation was continuously lobbying against the structural reform proposal at a high level. 
announced the withdrawal of the proposal in 2017. Concerning the structural reform, no joint EU regulation was adopted. ${ }^{23}$

At the same time, based on experience, the structural adoption of bank has taken place to some extent even without global regulation. ${ }^{24}$

The most recent stage of addressing the TBTF problem was that in 2019, the FSB put the comprehensive assessment of the TBTF reform on its agenda, examining:

1) Whether the introduced reform really reduce the systemic risk posed by SIB banks and the moral hazard. It is assessed to what extent the TBTF reform reduced the externalities due to SIB banks and enables the authorities to solve bankruptcy situations in an orderly manner that does not burden the taxpayers but is able to maintain basic economic functions.

2) The broader (positive or negative) effect of the TBTF reforms on the financial system is also examined. It is analysed to what extent the reform induced a change in the structure and activity of SIB banks, how it affected the security and structure of the financial system, the operation of the financial markets, global financial integration (including the problem of market fragmentation) and the availability and cost of sources of funding.

\subsubsection{Financial supervision}

As far as effective crisis prevention and crisis management are concerned, one of the most important safeguards is effective supervision. Among politicians and regulators there was a broad consensus on the poor performance of supervisory authorities before the crisis. Therefore, in addition to the elaboration of appropriate regulation, the measures taken after the financial crisis put special emphasis on the redefinition of the scope and limits of international prudential supervision and strengthening financial supervision. The responsibilities of the Financial Stability Board, which was set up for the global enforcement of macroprudential aspects, include the coordination of the work of standard-making bodies and the international harmonisation of supervisory practices. The trans-

23 In some EU Member States (e.g. in France, Germany and Belgium), rules restricting the trading activity of deposit-taking banks were adopted (BÁвоsıK, 2015).

24 According to the assessment of CGFS (2018), banks changed their business model in developed countries, turning from trading and complex activity towards less capital-intense activities. This is reflected by the change in the composition of their asset portfolio and income, as well as by the increased role of retail deposits. Large banks in the EU and the USA carry out a more selective and focused activity than earlier, while banks in large, developing economies and those in countries less affected by the crisis have spread internationally. 
formation of regulatory and supervisory systems, taking into account macroprudential risks, was prioritised. In order to avoid similar crises, the FSB believed that the establishment and operation of an early warning system was required. The system was set up within the framework of the cooperation of the IMF and the FSB. One of the main endeavours was to increase the scope of prudential supervision and extend it to all systemically important financial institutions, shadow banking activities and credit rating agencies.

Following the bank failures, it became obvious that there were contradictions between the global operation of internationally active banks and their national supervision. As the establishment or a gigantic supranational supervisory body was not a real option, regulators put the emphasis on supervisory cooperation and the improvement of the operation of supervisory colleges. (Supervisory colleges were set up in the case of each internationally active banking group.) Cooperation is supported by the document on the principles of the good practices of supervisory colleges, which the BCBS first issued in 2010 and is regularly revised and updated, with regard to recent developments (e.g. the activity of crisis management groups). ${ }^{25}$ The Committee also examines the implementation of the basic principles.

Regarding the effectiveness of supervision, well-defined data provision requirements are crucial. In view of the above, the BCBS was following whether G-SIB banks were prepared for the provision of aggregate data on risks. The document on the principles and practices of the stress test promotes the improvement of the supervisory toolkit and techniques, as well as the development of good practices. I addition, it draws attention to the role of supervisory and macroprudential authorities. The reports describing the practice of early supervisory intervention was also meant to support strong supervision.

The report on the predictability and effects of banking supervision aimed to improve effectiveness, as well. The Committee also examined how the principles of effective banking supervision have to be applied in the case of institutions which play an important role in financial inclusion (integration).

The FSB report on enhanced supervision also contributes to increasing the efficiency of supervisory work. The document summarises the means and methodologies of the consolidation of supervision, which are primarily required when the capital and liquidity of an institution are inadequate. The guide on the frameworks of the evaluation of risk culture pays special attention to the interaction between supervisory authorities and financial institutions, while the thematic review on

25 Special reports are made on the supervisory colleges of financial conglomerates. 
supervisory frameworks and approaches for SIBs deals with the progress that has been made since the crisis.

\subsubsection{Responsible corporate governance, compensation policies}

In addition to prudential regulation and the reform of financial supervision, the regulatory priorities expressed at global level also included the improvement of corporate governance and risk management. ${ }^{26}$ In view of the above, based on the experience gained during the financial crisis, the BCBS reviewed and modernised its guidelines on responsible corporate governance already in $2010 .{ }^{27}$ The crisis revealed that the board of directors and the senior management often did not understand the risks borne by the bank. In the light of this, it was necessary to revise and amend the guidelines regarding directorial practices, risk management, transparency and knowledge of the institution's own organisational structure. The major duties of the corporate governance of banks was reviewed, guidelines on the board of directors, senior management, risk management, internal auditing, compensation, corporate structures, disclosure and transparency were issued. During the discussions, the responsibilities of supervisory authorities were treated as high-priority issues, as the supervisory authorities play a crucial role in allowing banks to enforce the principles of responsible corporate governance.

From the perspective prioritising the risk-consciousness of corporate governance, the BCBS revised its guidelines again. The guidelines revised and published in 2015 include 13 principles on the general responsibility of the board; the qualification and composition of the board, the structure and procedures of the board, the senior management, the governance structure of the group, risk management, the identification and monitoring of risks, risk communication, compliance with the rules, internal auditing, compensation, disclosure, transparency and the role of supervisory authorities.

In 2017, the FSB examined the introduction of corporate governance principles by financial institutions in an expert report. The report established that the comprehensive regulatory frameworks had been set up in all jurisdictions of the FSB. However, the effectiveness of their use may be decreased if there is no clear task-

26 The establishment of responsible corporate governance and appropriate banking culture are key elements in the restoration of consumer confidence. For further details on this, see: PESUTH (2016).

27 The basic document on responsible corporate governance is the G20/OECD's Principles of Corporate Governance, which was adopted in 1999 and is considered to be one of the key standards of the FSB. The World Bank regularly assesses to what extent the rules of the member countries on responsible corporate governance comply with the aforementioned standards. On this subject, the BCBS issued its first guideline in 1999, which was amended in 2006. 
sharing between the authorities of the financial sector, the rules are overlapping, contain loopholes or are inconsistent.

Within the frameworks of responsible corporate governance, the regulators, especially politicians, devoted special attention to the issue of compensation for senior managers. The starting point of this endeavour was the 2010 recommendation by the Financial Stability Board (Principles and Standards for sound compensation practices (P\&S)). The most important elements of this included linking risk-taking to remuneration, strengthening the awareness of risks, limiting the proportion of changing income elements and linking them to long-term successfulness. A further requirement was that the compensation of the senior management had to reflect the loss of the company and that the remuneration could also be reduced. The principles shall be applied at financial institutions which are significant regarding compensation.

The document on compensation principles and standards of assessment methodology issued by the BCBS provides guidance for the supervisory authorities regarding the assessment of the compensation practice of the individual institutions and judgement the compliance of the given compensation practice with the relevant principles and application standards of the FSB. In its document on the methodologies for the harmonisation of the compensation for risk and performance assessment, the Committee analysed the methods used by the banks to consider risk factors when establishing bonus policies and individual compensation schemes.

In 2018, by taking into account misconduct risk, the FSB amended its recommendation on compensation practices. ${ }^{28}$ The FSB set up frameworks regarding how the regulations on bonus adjustments, maluses and repayment obligations due within one year can be used for reducing conduct risk and handling actual abuses.

The FSB is monitoring the implementation of compensation norms; in 2019, the sixth status report was published on the practical implementation of FSB's principles on appropriate compensation and application standards. The $P \& S$ report points out the banks concerned have introduced and are applying the procedures and practices on compensation procedures restricting inappropriate risk-taking, but the actual effectiveness of the measures has not been proven yet. In fact, such procedures and practices are still being tested. In spite of this, it can be stated that the boards control compensation processes better than earlier, compensation contracts are concluded for a longer term and are better tailored to effective risk management. Despite the fact that the regulation applies to the senior managers

28 This risk type came to the fore due to cases of interest rate fraud. 
as well as the employees who take actual risks, the most basic risk-related compensation rules are increasingly applied to all employees. In addition to the approach focusing on conduct risk, there is stronger emphasis placed on the method with which the boards achieve the desired behaviour and cultural change. As far as compensation practices are concerned, the banks also pointed at the competition from fintech companies and the lack of a level playing field deriving from the differences of approach of the individual jurisdictions.

Experience has also shown that jurisdictions typically apply compensation rules only to banks, while only a few jurisdictions extended the application of the recommendation to insurance companies or fund managers.

\subsection{European regulation}

\subsubsection{Capital requirements regulation and directive}

\subsubsection{The adoption of Basel III}

At EU level, the BCBS decisions on global capital and liquidity regulation were followed by the amendments to the Capital Requirements Directive (CRD2, $\left.\mathrm{CRD}_{3}, \mathrm{CRD} 4\right)$, and the adoption of the Capital Requirements Regulation (CRR) with some delay.

The first serious amendment to the directive was CRD2, which the Member States has to apply as of 31 December 2010. CRD2 dealt with large exposures, hybrid capital items, the division of labour by supervisory authorities and their cooperation in crisis management, as well as the management of securitised positions. CRD 3 included rules on the capital requirements of the trading book, the capital requirement of resecuritised positions (complex securitisation), disclosure requirements regarding securitisation, as well as remuneration policies and practices. ${ }^{29}$ In accordance with the amendment, the capital limits based on the Basel I Accord (the capital cannot be less than $80 \%$ of the capital calculated pursuant to the Basel I rules) remained in effect even after 2009. The rules on remuneration broadly

29 The amendments $\mathrm{CRD}_{2}$ and $\mathrm{CRD}_{3}$ reacted to global decisions taken prior to Basel III relatively fast. However, the adoption of the rules on hybrid capital items codified the practise evolving in the Member States based on the Sydney press release of 1998. Consequently, in the European Union, the rules on setting off hybrid capital items were established with significant delay when the improvement of the quality of capital was on the global agenda. Hybrid capital elements had to be involved so that later regulation could provide an adequate transitional period for phasingout such elements from the capital. 
complied with the relevant principles of the Financial Stability Board, however, in some respects, they succeeded those. ${ }^{30}$

The consultation document of CDR4 published in February 2010 basically corresponded to the consultation documents of Basel III published by the Basel Committee in December 2009. The document made proposals in connection with liquidity management, the improvement of capital quality, the introduction of leverage ratio, the counterparty risk management, the clearing of OTC derivatives through central clearing counterparties, the improvement of the countercyclical character of regulation (the introduction of capital reserves and prospective, dynamic provisioning), the complementary regulation of systemic institutions and a European single rule book.

After the consultation, the new European Commission had to submit the new version of the regulation. At the end of July 2011, the European Commission published its regulatory proposal for the introduction of the Basel III Accord in Europe. In addition to showing respect for the entire Basel Accord, the proposal also included certain European characteristics (the home/host aspects in the field of the definition of capital and liquidity regulation, as well as grandfathering). The Commission drew up the new rules partly as a regulation (CRR), partly as a directive $\left(\mathrm{CRD}_{4}\right)$. The directive regulated the approval of the activity (rules on minimum capital), supervisory cooperation and exchange of information, the frameworks of consolidated supervision, including liquidity supervision and the role of auditors. The new elements of the directive included provisions on the sanctions for the infringement of the rules, rules on effective corporate governance and measures against excessive reliance on external credit rating (measures to encourage internal rating). Among the important elements of the Basel III Accord, the directive includes rules on capital conservation and countercyclical buffer.

The prudential rules of the Basel III Accord, except for the measures on capital buffer, can be found in the regulation. The regulation shall be directly applied in all countries of the European Union, ensuring level playing field and preventing different national interpretations. A further advantage of the regulation is that subsequent amendments can be applied faster (almost immediately after adoption). At the same time, the aim of the form of regulation was to promote the creation of the European Single Rule Book.

30 Being afraid of the loss of competitiveness of the London-based City, the British were lobbying hard against the adoption of compensation rules.

In practice, the observance of compensation rules not tailored to them is an actual problem for smaller European institutions. 
The proposal about the CRR sought to abolish former national discretions and options, but it allowed Member States to apply stricter rules in some specific, welldefined areas. Based on the above, decisions on the capital requirement for mortgage loans, the prescription of additional capital requirement under the second pillar and the extent of countercyclical excess reserves can be taken at national levels. The regulation specifies the definition of capital, corrects the treatment of securitisation and trading book items, establishes the capital requirement for the counterparty risk arising from OTC derivatives and introduces liquidity rules in accordance with the Basel III Accord. Disregarding the principle of risk sensitivity, the CRR extended the $80 \%$ limit requirement until 2015, however, it enabled greater recognition of risk-mitigation techniques. The regulation also touched upon the scope of the European Commission and the European Banking Authority (EBA).

In order to reach an agreement on the regulatory proposal, a so-called flexibility package, which provides some leeway for the Member States, was accepted. Pursuant to this package, national authorities shall be entitled to prescribe systemic risk excess reserves (buffers) in three categories (for systemically important global institutions, other systemically important institutions and as systemic risk buffer). Beyond buffers, the responsible authorities shall have the right to take national-level measures to manage systemic and macroprudential risks, including sensitive areas such as the level of equity or the risk weight of receivables secured by commercial or residential property. (However, upon the proposal of the Commission, drawn up in agreement with the EBA and the ESRB, shall have the right to reject national measures.) The adopted text represents a change favourable regarding minority interests, lending to SMEs, the management of trade financing, credit valuation adjustment (CVA), the application of prudential filters, the weighting of receivables in foreign exchanges of other Member States against central governments and central banks, as well as liquidity requirements. The change applying to liquidity was in accordance with the rules adopted by the BCBS.

The regulation fundamentally determining the operating conditions of European banks entered into force as of 1 January 2014.

\subsubsection{The Risk Reduction Package (RRP) of November 2016}

The changes adopted in the frameworks of the Basel III regulation since 2010 had to be included in the European regulation, as well. In November 2016, the European Commission released a communication on the review of the regulation of financial services. Based on an extensive Call for Evidence, the European Commission suggested measures related to financial regulation in the following four areas in its communication: 
- Lifting unnecessary regulatory barriers which prevent the financing of the economy.

- Improving the proportionality of rules.

- Reducing unnecessary regulatory (compliance) burden.

- Strengthening the consistence and the progressive character of the rules.

Together with the communication, the European Commission also published its proposal on finalising the transposition of the Basel reform package that contains the amendments to the Capital Requirements Regulation and Directive, Bank Recovery and Resolution Directive (BRRD) and the Single Resolution Mechanism Regulation (SRMR). ${ }^{31}$ The rules were established on the basis of adopted global standards, taking into account the characteristics of the European banking sector. The regulatory packages include measures to (i) increase the resilience of EU institutions, enhance financial stability, (ii) improve the lending of banks to support the EU's economy and (iii) facilitate the role of banks supporting the establishment of the capital market union.

The major elements of the Commission's proposal for increasing the resilience of EU banks concerning CRR/CRD4 were the following: the introduction of a leverage ratio of $3 \%$; the introduction of a net stable funding ratio; a radical reform of the trading book regulation; simple, transparent and comparable (STC) securitisation, as well as the reduction of the capital requirements of covered bonds; the reservation of the SME support factor and its extension to all SME loans; decreasing the capital requirements of infrastructure projects; increasing proportional use: in the case of smaller banks, reduction of the reporting and disclosure requirements, simplification of the calculation of capital requirements for trading positions, easing remuneration rules and the modification of the rules on taking large exposures. ${ }^{32}$

In connection with the establishment of the European Single Rule Book, The European Banking Authority endeavoured to harmonise and simplify reporting requirements (COREP, FINREP).

The risk- reduction package was adopted at the end of 2018, following the conclusion of the tripartite negotiations. On the other hand, the adopted rules contain several compromises, some of which diverge from global rules. Most banks criticised decision-makers for not removing the trading book regulation of 2016 from

31 The two latter are to be detailed later.

32 The amendment to the CRR was put on the agenda for other purposes, as well: e.g. the regulation of covered bonds and the treatment of NPL loans. 
the regulation completely, therefore the institutions had to perform their reporting requirements pursuant to an obsolete standard until the implementation of the new FRTB. Another reason for criticism is that the regulation did not promote the movement of capital and liquidity to the desired/reasonable extent within the banking group at least in the case of the Banking Union. Regarding competitiveness, the EU banks considered the deduction of the software from solvency capital as a priority issue, as well. According to the final decision, some software will be exempt from the deduction from the solvency capital under the conditions to be drawn up by the EBA.

The European Commission intentionally did not amend the RRP with the decisions adopted by the BCBS in December 2017 (Basel IV). After conducting comprehensive impact assessment, a special proposal is to be made on the implementation of these decisions.

\subsubsection{Tackling the TBTF problem - Bank resolution frameworks}

Based on the logic of the European single market, the European Union paid special attention to the establishment of single crisis management frameworks. Already the initial documents on the topic (from 2009 and 2010) include ideas such as the establishment of joint reorganisation/solution funds, setting up resolution authorities, drawing up recovery and resolution plans and creating a crisis management toolkit.

In many respects, European efforts preceded the establishment of global frameworks, therefore subsequent harmonisation was necessary in some cases.

The rules of crisis management were laid down in the directive establishing the framework for the recovery and resolution of credit institutions and investment firms (BRRD) adopted in 2014. The directive harmonised the regulations of the Member States, but due to the legal environment (rules of company law and liquidation), adopting a regulation was not reasonable. In line with the scope of the Capital Requirements Regulation and Directive, the provisions of the BRRD shall apply to all credit institutions and investment firms, irrespective of their size and activity. As opposed to common insolvency proceedings, the special frameworks for the management of banking crisis allow the use of tools and techniques which consider the characteristics of banks, thus ensuring the continuity of service and the defence of the depositors.

The BRRD prescribes Minimum Requirements for own funds and Eligible Liabilities (MREL) which shall be fulfilled by all banks. Despite playing the same role regarding their content, the MREL requirements did not exactly correspond to the TLAC rules adopted by the FSB later. Consequently, the latter had to be 
implemented in the European regulation by 1 January 2019, which took place by adopting the risk reduction package.

Within the RRP, the most important elements of the amendment to the BRRD were

- the integration of TLAC rules on G-SIBs into the MREL requirements (the TLAC rules had to be performed by 13 EU banking groups),

- the harmonisation of the regulation of creditors hierarchy to increase the legal security of investors and resolution authorities ${ }^{33}$,

- as well as the consolidation and harmonisation of the right of imposing a moratorium to facilitate early intervention by the authorities.

Concerning the amendments, restricting the sale of MREL instruments to retail clients should be mentioned, as well. It is also important that, in accordance with international practice, the use of moratorium tools was limited to 48 hours. It was also pointed out that the liquidation of institutions which were failing or likely to fail (FOLF), but not to be resolved, had to be implemented in an orderly manner, in accordance with the relevant rules of the national law.

The RRP also included an amendment to the Single Resolution Mechanism (SRM), leading to the operation of the Banking Union..$^{34}$

\subsubsection{The Banking Union}

The decision on the establishment of the Banking Union was taken as a response to the crisis of the euro zone in the summer of 2012 to break the vicious circle of banking crises and sovereign crises (potential state bankruptcies). In a different sense, the Banking Union can be considered as a way of tackling the TBTF problem, as it places the problems caused by systemically important banks into a broader perspective than that of the nation state. The Member States using the euro are automatically members of the Banking Union, while the Member States outside the euro zone can join under specific conditions. The four pillars of the Banking Union include (i) the European Single Rule Book (discussed earlier) that is to be applied in all EU Member States, (ii) the Single Supervisory Mechanism (SSM), (iii) the Single Resolution Mechanism (SRM) and (iv) the European Deposit Insurance System (EDIS).

The Single Supervisory Mechanism was set up in November 2014. Today, the SSM can be considered to be a well-established, well-functioning element of the

33 This provision was approved in a special procedure at the end of 2017.

34 This article does not aim to provide a description of the detailed regulation of the Banking Union, only highlights the most important elements. 
Banking Union. Within the framework of the SSM, the European Central Bank (ECB) directly supervises significant banks. Less significant banks are indirectly supervised by the ECB. ${ }^{35,36}$ Transition to the SSM was preceded by the comprehensive assessment to explore problems inherited from the past, whose elements included supervisory risk assessment, Asset Quality Review (AQR) and a stress test conducted in close cooperation with the EBA. ${ }^{37}$

Following the establishment of the SSM, the ECB also played an active role in setting up the regulatory frameworks, therefore, it was an initiator in the standardisation of national options and discretions, reducing their numbers or treating NPL loans..$^{38}$ The ECB puts great emphasis on the consistent operation of joint supervisory groups and the standardisation of the Supervisory Review and Evaluation Process (SREP). The multiannual programme called Targeted Review of Internal Models seeks to promote the correct, consistent and comparative determination of capital requirements and the restoration of the credibility of model usage.

Another important pillar of the Banking Union, the Single Resolution Mechanism, started its full operation only in 2016, pursuant to the relevant regulation. The establishment of the SRM was supported by Commission's delegated regulations, related to the BRRD and the SRMR.

Within the SRM, the Single Resolution Board (SRB) acts as the fully responsible resolution authority of significant institutions and a further 15 cross-border banking groups. The first tasks of the SRB included the establishment of the frameworks of resolution planning (Resolution Planning Handbook) and the elaboration of the reports required for resolution planning and specifying the data requirements for the determination of MREL. Subsequently, the SRB set the consolidated MREL

35 The ECB and the national supervisory authorities took a joint decision on the significant institutions to be placed under the direct supervision of the ECB. The decision was taken on the basis of the figures from the end of 2013. On the whole, 120 institutions/groups were found to be significant (97 based on their size (a balance sheet total exceeding EUR 30 billion), 13 due to their economic importance (a balance sheet total exceeding $20 \%$ of the GDP of the country where the institution is based, but at least a balance sheet total of EUR 5 billion), 3 due to their cross-border activities and 7 based on the fact that they were among the 3 largest credit institutions in the given Member State). The list is revised annually.

36 Along with other aspects, the ECB became the supervisory authority of the SSM, because this solution did not require the amendment of the Treaty on the European Union.

37 The AQR aimed to filter out banks with bad asset quality an inadequate capitalisation. Within two weeks, the banks filtered out had to submit a plan of capital, which was evaluated by the joint supervisory groups.

38 Regarding the latter, the ECB pushed its limits, because, as a supervisory authority, it is not entitled to adopt general rules. To solve the problem the ECB prescribed for individual institutions to fulfil the requirements. 
value compulsory for more significant banking groups, then, on the basis of risk profiles, the institution specific, individual MREL values. The core tasks of the $\mathrm{SRB}$ also include the elaboration of resolution plans, putting them into operation, the assessment and support of resolvability and the removal of its obstacles. ${ }^{39}$ In addition to the above, other priorities are providing critical functions, access to financial market infrastructure, liquidity during resolution and the preparation of effective, cross-border resolution.

By the end of June 2019, the banks of the member states of the Banking Union paid EUR 33 billion in total to the Single Resolution Fund. ${ }^{\circ}$ At the time when the SRM was established, the member states agreed that the operability of the Single Resolution Fund is to be increased by setting up a common fiscal backstop for protecting financial stability. It was to provide the additional funds required for resolution after the bail-in of creditors. Based on a political decision taken in 2018, the fiscal backstop means the credit line provided by the European Stability Mechanism. (The codification of the decision is still in progress.) There is no real experience regarding the operation of the SSM. The bank failures which have taken place since its establishment, have been treated in atypical ways.

Despite several attempts, the European Commission has not managed to set up a European Deposit Insurance System. The failure was owing to the conflict between the more developed northern Member States and the less developed southern Member States. According to the former countries, the level of reducing the risks posed by the financial system achieved so far is not enough for the introduction of a common deposit insurance system.

Beyond the political circumstance, the stability of the Banking Union is also threatened by the fact that a firm decision to establish a common fiscal policy does not exist. The vicious circle connecting the sovereign and the banking crises has been broken only partly. Due to capital and liquidity regulation, banks have a strong interest in holding government bonds. The government securities denominated in euro have zero risk weight within the Banking Union, which means that the regulation does not distinguish between the riskiness of the Member States. Consequently, the banks' exposure to the Member States with high debt can remain unchanged. At the same time, the drop in the price of bonds

39 The SRB, in close cooperation with the national authorities, is working on the creation of more than 100 resolution plans. In 2018, banks were divided into two groups: first, resolution plans for the banks within the Banking Union (i.e.: banks without resolution college) were drawn up. The resolution plans for complex, internationally active banks (having a resolution college) are to be finalised in 2019. The completed plans are being continuously revised.

40 The final provisioning target level of EUR 55 billion, which amounts to $1 \%$ of guaranteed deposits, shall be reached by 31 December 2023. 
has a direct effect on the solvency of the banks holding the bonds, decreases their creditworthiness, increases financing costs, and, in extreme cases, can result in bank failures. ${ }^{41}$

\subsubsection{The new European supervisory structure}

One of the well-definable consequence of the crisis was that, as opposed to earlier intentions, the transformation of the supervisory structure took place in Europe within a shorter deadline and faster. The relevant regulatory package was drawn up on the basis of the report by a high-level expert committee, the de Larosière group.

Legislators set up the macroprudential European Systemic Risk Board (ESRB) responsible for the stability of the financial system, as well as the European Banking Authority (EBA), the European Securities and Markets Authority (ESMA), the European Insurance and Occupational Pensions Authority (EIOPA), authorities in charge of the supervision of banks, securities markets, insurance companies and occupational retirement schemes. The aforementioned authorities took over the activities, duties and obligations of the former ${ }_{3} \mathrm{~L}_{3}$ Committees (CEBS, CESR, CEIOPS), receiving additional rights, extra responsibility and scope and being legally authorised to, inter alia, elaborate technical standards, settle conflicts between national supervisory authorities, ensure the consistent enforcement of technical Community rules, temporarily ban or limit the activities if financial stability is threatened, and coordinate national supervisory authorities in crisis situations. In addition, the ESMA directly supervises credit rating agencies.

The supervisory authorities were established in three separate regulations. The new European Supervisory Authorities (ESAs) are EU bodies with legal personality. Their binding decisions shall not directly affect the budget of the member states. The new authorities belong to the European System of Financial Supervision (ESFS), which also includes the ESRB, the Joint Committee of European Supervisory Authorities responsible for the supervision of financial conglomerates, the national supervisory authorities and the European Commission.

In accordance with the rules effective as of 1 January 2011, the national authorities remained responsible for daily supervision and the bailout of individual institu-

\footnotetext{
41 Several suggestions have been made on how to break the vicious circle: e.g.: the introduction of appropriate risk weights, limiting the amount of government securities which can be held, replacement of sovereign bonds by a senior series of a diversified portfolio and the introduction of a new secure instrument in the euro zone etc. In its 2017 report, the BCBS recommended several possible treatment methods, but no consensus was reached, as holding government bonds by banks is an important means of debt management in several countries (SIRONI, 2018).
} 
tions. Cross-border groups were supervised by supervisory colleges, in the work of which the European Supervisory Authorities took part as full members. ${ }^{42}$ The ESAs played a key role in the harmonisation of guarantee systems (deposit, investor and insurance client protection), as well. Their scope of duties includes the initiation and coordination of EU-level stress tests in cooperation with the ESRB. Normally the ESAs receive the information required for their operation from the national authorities, but, in justified cases, they are entitled to request information directly from financial institutions.

The integration of the new supervisory structure in previous laws was ensured by the adoption of the so-called "omnibus" directive.

According to the assessment by the European Commission, since they were set up, the ESAs have been playing a central role in ensuring well-regulated, strong and stable European financial markets. The ESAs have contributed to drawing up the single rule books of financial services, the convergence of supervisory practices, the establishment of the robust financial frameworks of the single market and the foundation of the Banking Union.

In 2016, the European Commission believed that it was time to collect feedback and information on the operation of the European macroprudential regulatory frameworks, therefore it launched a consultation process on the subject. The Commission seeks to create consistency among the five regulatory elements of the macroprudential regulatory system (the two regulations on the European Systemic Risk Board, the Capital Requirements Regulation (CRR), the Capital Requirements Directive (CRDIV) and the Single Supervisory Mechanism Regulation (SSMR)) by filtering out overlaps and possible conflicts. The consultation included questions related to tightening and refining existing macroprudential tools (e.g. capital buffers), but it also covered the organisational structure of the ESRB and its relationship with the European Central Bank.

In March 2017, the European Commission launches a public consultation about the operation of the European Supervisory Authorities, as well. The consultation covered (i) the responsibilities and scope, (ii) the management, (iii) the structure and (iv) financing of the ESAs.

Following the consultations, in September 2017, the European Commission proposed the reform of the European supervisory structure in order to further expand financial integration and the Capital Markets Union..$^{43}$ The proposal

42 Of course, after the establishment of the Banking Union, these powers changed, but regarding the EU banking groups operating within or outside the Banking Union, they are still valid.

43 This article does not deal with the regulatory frameworks facilitating the establishment of the Capital Markets Union and outlining capital market rules (MiFID, MiFIR, EMIR). (The global 
extends the mandate of the European Supervisory Authorities, improves their management system and financing. It would give direct supervisory powers to the ESMA in special segments of the financial sector. The Commission also proposed changes in the organisation and composition of the European Systemic Risk Board. The changes affect relations with non-EU supervisory authorities, as well. According to the Commission's proposal, supervisory coordination within the EU shall be strengthened. The ESAs specify EU-level supervisory priorities and control whether the work programmes of the supervisory authorities of the Member States are consistent with the common priorities. They also monitor supervisory practices related to controlling the relocation and outsourcing of the market participants' activities to non-EU countries. The EIOPA plays a greater role than earlier in facilitating the convergence of the internal model validations used by insurance companies. The ESMA's supervisory powers in the capital market will be extended. Based on the proposal, ESMA shall permit and supervise the authoritative benchmarks of the EU and approve of the use of non-EU benchmarks in the EU. The powers of the ESMA shall also include the approval of certain EU and all non-EU issue brochures, as well as the supervision and approval of European investment funds. The organisation shall play a more prominent role in the investigation and coordination of market abuse, as well.

The proposal made the decisions taken by the ESAs more independent of national interests. In the new governance structure, boards with permanent members would be set up (Executive Boards), which would enable faster, more targeted and EU-centred decisions. The reform would make the financing of the ESAs independent of the national authorities. The required resources would be provided not only by the budget of the EU, but also by the financial sector.

Influenced by the Latvian, Maltese and Danish money laundering scandals, the EU Commission amended it proposal under negotiation in September 2018. The amendment proposed the reinforcement of the supervision of financial institutions in order to improve the fight against money laundering and terrorism finance. The proposal would strengthen the mandate of the European Banking Authority regarding the supervision of the anti-money laundering fight, making it more comprehensive and understandable, with clearly defined responsibilities, appropriate powers and resources. Among the ESAs, it is the EBA that is authorised to supervise money laundering, as in most cases, money laundering and the financing of terrorism pose a systemic risk for the banking sector. Although, due to significantly diverging views, the original regulatory proposal on the financial

rules on OTC derivatives were implemented in the European regulation by the EMIR on OTC derivatives, central counterparties and trade repositories.) 
supervisory system is still far from adoption, concerning amendment, an agreement had been reached within the Council by the end of 2018 , therefore it was possible to launch an independent trilogue at the beginning of 2019.

\section{ASSESSMENT OF THE REFORMS FOLLOWING THE CRISIS}

\subsection{Regulatory monitoring and assessment}

\subsubsection{The assessment of the introduction of the reforms by the FSB}

As the introduction of the reforms is progressing, there is an increasing need for the assessment of the actual effects. In 2017, the FSB elaborated and published the frameworks for the assessment following the introduction of financial regulatory reforms. The FSB developed the analytical frameworks in close cooperation with other regulators and interested parties, taking into account the results of the public consultation. The elaborated frameworks help to analyse whether the reforms have had the desired results or whether they have had an unintended effect that should be treated, without threatening the aim of the reform. The methodology defines concepts, terminologies, analytical methods and procedures for the assessment. In the light of the feedback and experience, the framework is being continuously fine-tuned.

The assessment of the introduction and effectiveness of the regulatory standards adopted by the FSB is also supported by the Handbook for FSB Peer Reviews, which was first adopted in 2009, and then it has been updated several times. ${ }^{44}$

In November 2018, the FSB already published its fourth annual report on the introduction and effects of the G2O regulatory reforms. ${ }^{45}$ The report states that the new rules requested by the G2o were adopted, their implementation is making good progress and the only remaining rule-making work is related to the insurance sector and the central counterparties. In connection with the problems arising from the crisis, it points out:

- The capitalisation of large banks is better, they operate with lower leverage and are more liquid. As a result, the banking system is more resistant to possible shocks.

- The implementation of the TBTF reforms is proceeding well, including the establishment of resolution systems.

44 There are two types of assessment (thematic and country-specific) and they consist of five sections (definition of priorities, preparations, consultation, assessment and follow-up). The aforementioned sections are described in detail in the handbook.

45 FSB (2018) 
- The OTC derivate markets are more simple and transparent. The use of central clearing and the role of guarantees have increased.

- The features of non-banking financial intermediation which contributed to the crisis have significantly weakened and do not pose a stability risk in general.

\subsubsection{Monitoring and assessment of the rules by the BCBS}

The BCBS puts great emphasis on the comprehensive and efficient implementation of the adopted standards within the agreed timeframes. Within the framework of the Regulatory Consistency Assessment Programme (RCAP), they have regularly published reports on the introduction of the rules since 2012, presenting the situation by jurisdiction and regulation type. The latest reports consider the rules finalised in December 2017, as well. The recent report assesses the introduction of risk-based capital rules, the leverage ratio, the requirements for systemically important global and domestic banks (G-SIBs, D-SIBs), the IRRBB frameworks, the NSFR, the large exposure rules and the disclosure requirements.

The Commission examines the effects of the Basel III regulation on institutions every six months. ${ }^{46}$ The monitoring report, which was published in March 2019 for the 16th time, presents the change of different indicators through the data of 189 banks (106 of them were large, internationally active banks) recorded on 30 June 2018, assuming the full-scale introduction of the rules finalised in 2017. (The finalised FRTB was not considered yet.) In the course of the examination, the banks were divided into two groups: the first group (Group 1) consisted of banks with tier1 capital over EUR 3 billion, while the second group (Group 2) included internationally not active banks with a capital under EUR 3 billion. The data of G-SIB banks were published separately, as well (see: Table 4).

46 Similar analyses are prepared for European banks every six months by the EBA. 
Table 4

The Basel III monitoring result of March 2019

\begin{tabular}{|c|c|c|c|c|c|c|}
\hline & \multicolumn{3}{|c|}{31 December 2017} & \multicolumn{3}{|c|}{30 June 2018} \\
\hline & Group 1 & $\begin{array}{l}\text { Out } \\
\text { of this: } \\
\text { G-SIB } \\
\text { banks }\end{array}$ & Group 2 & Group 1 & $\begin{array}{l}\text { Out } \\
\text { of this: } \\
\text { G-SIB } \\
\text { banks }\end{array}$ & Group 2 \\
\hline \multicolumn{7}{|c|}{ The original Basel III frameworks with complete introduction } \\
\hline CET1 quotient (\%) & 12.9 & 12,6 & 16,0 & 12,7 & 12,5 & 15,5 \\
\hline $\begin{array}{l}\text { Capital shortfall compared } \\
\text { to the target ( } € \text { billion); } \\
\text { out of this: }\end{array}$ & 0.0 & 0.0 & 1.1 & 0.0 & 0.0 & 2.0 \\
\hline CET1 & 0.0 & 0.0 & 0.0 & 0.0 & 0.0 & 0.0 \\
\hline $\begin{array}{l}\text { Additional common equity } \\
\text { (Additional Tier } 1 \text { ) }\end{array}$ & 0.0 & 0.0 & 1.1 & 0.0 & 0.0 & 1.9 \\
\hline Tier 2 capital & 0.0 & 0.0 & 0.0 & 0.0 & 0.0 & 0.1 \\
\hline $\begin{array}{l}\text { TLAC shortfall compared to the } \\
2022 \text { minimum ( } € \text { billion) }\end{array}$ & 82.1 & 82.1 & & 68.0 & 68.0 & \\
\hline Balance sheet total ( $€$ billion) & 64.040 & 41.408 & 4.256 & 64.959 & 43.677 & 4.434 \\
\hline Leverage ratio (\%) & 5.8 & 5.9 & 5.7 & 5.8 & 5.8 & 5.4 \\
\hline LCR (\%) & 133.0 & 129.0 & 180.0 & 135.1 & 132.0 & 180.2 \\
\hline NSFR (\%) & 116.0 & 118.0 & 118.5 & 116.0 & 117.1 & 119.2 \\
\hline \multicolumn{7}{|c|}{ The final Basel III frameworks with complete introduction (2027) } \\
\hline $\begin{array}{l}\text { The change of the capital } \\
\text { adequacy ratio calculated } \\
\text { for common equity compared } \\
\text { to the target level (\%) }\end{array}$ & 3.2 & 2.8 & 5.8 & 5.3 & 5.7 & 9.0 \\
\hline Without FRTB effects & 1.7 & 1.2 & 5.3 & 1.7 & 1.5 & 8.3 \\
\hline CET1 quotient $(\%)$ & 12.2 & 12.0 & 12.6 & 11.7 & 11.6 & 13.0 \\
\hline $\begin{array}{l}\text { Capital shortfall compared } \\
\text { to the target ( } € \text { billion); } \\
\text { out of this: }\end{array}$ & 25.8 & 23.7 & 2.5 & 30.1 & 29.3 & 6 \\
\hline CET1 & 5.2 & 5.2 & 1.0 & 7.0 & 7.0 & 2.2 \\
\hline $\begin{array}{l}\text { Additional common equity } \\
\text { (Additional Tier } 1 \text { ) }\end{array}$ & 7.3 & 6.3 & 0.8 & 10.6 & 10.3 & 2.3 \\
\hline Tier 2 capital & 13.3 & 12.2 & 0.7 & 12.6 & 12 & 1.4 \\
\hline $\begin{array}{l}\text { TLAC shortfall compared to the } \\
2027 \text { minimum ( } € \text { billion) }\end{array}$ & 143.6 & 143.6 & & 108.8 & 108.8 & \\
\hline
\end{tabular}

Note: ${ }^{\star}$ Minimum Required Capital

Source: BIS 


\subsubsection{The Chairperson of the SSM about the regulatory reform}

Andrea Enria, the new Chairperson of the SSM, gave the following answer to the question about the appropriateness of the reforms (whether they are inadequate or go too far):

"The reforms were needed. The crisis revealed several deficiencies of the regulatory frameworks which had to be eliminated. I believe that the package prepared by the G2o countries is well-balanced: it has significantly increased the security and stability of banks. The requirements were quantified and introduced in a manner that will not threaten lending and real growth. In certain areas, some jurisdictions exceeded the requirements set by international standards, therefore currently, they are reviewing their decisions. In general, I think that in good periods, we must resist the pressure to loosen the requirements. As I mentioned earlier, banks, as well as supervisory authorities, must resist short-term thinking. Bearing in mind the long-term stability of the system, procyclical rulemaking should be avoided.

At the same time, of course, it is true that the reviewed rule book is fairly complex. Consequently, we should follow its effects and make adjustments if necessary. However, our current priority is complete the consistent global introduction of the reforms." ${ }^{37}$

\subsection{Subjective assessment - Is this the regulation they really wanted?}

In this subchapter, I make short statements about the regulation after the crisis, it effects, then I try to support or, to some extent, refute the statements by citing mainly expert opinions.

\subsubsection{The effect of the regulation on the banks and the economy}

As a result of the regulation, the capital and liquidity of the banking sector actually became stronger.

Everyone agrees with this statement, the semi-annual monitoring statements of the BCBS clearly support it. By contrast, it is a controversial question whether the post-regulation capital level, which is significantly higher than the capital level prior to the crisis, is high or sufficient enough to resist future crises. Some expert who raise this question argue for the necessity of the prescription of more stringent capital requirement, while others doubt that the sufficient/optimal level of

47 ECB (2018) 
capital can be determined at all..$^{8}$ According to Mervyn King, the Governor of the Bank of England: The main lesson we can learn from the crisis is that the capital that seems to be sufficient today, will not be enough tomorrow. It is impossible to determine the optimal level of capital. Before the crisis, hardly any capital was needed if a bank wanted to take out a non-guaranteed loan. However, after the crisis, banks did not have access to such resources at all. ${ }^{49}$

Raihan Zamil also argues that no amount of capital is sufficient for setting off the lack of appropriate asset selection and assessment standard. Appropriate risk management (banking function) and competent supervision (function of the authority) cannot be simply replaced by the capital adequacy ratio. A 5\% decrease in the asset value results in the drop of the capital adequacy ratio to $52 \%$. Increasing the capital adequacy ratio to $15 \%$ will not considerably change this ratio. Good capital supply is meant to alleviate the crisis, but it may hide the real state of the financial system. ${ }^{50}$

Based on the experience gained in Japan in the 1990s, the research group of the Japanese Banking Association is of a similar opinion. During the financial crisis of the 1990s, capital requirements were not tightened, but banks were encouraged to improve their risk management instead. The process included the strict assessment of loss-making assets, carving out non-performing loans and even capital increase if needed. Complex problems cannot be treated in a simple way, by setting higher capital requirements..$^{51}$

It is even more doubtful whether compliance with the compulsory liquidity indicators would protect from the drying up of the market in the event of a system-level crisis. The management of such crisis situations is unimaginable without centrally guaranteed liquidity. According to Mervyn King, the connection of funding by the central bank and the regulation of liquidity is another fundamental question. It has been shown by past events that in a crisis, the central bank is the exclusive source of liquidity. Liquidity regulation cannot be

48 According to Admati (2019): According to the banking mantra, the statement "capital is too expensive fails to distinguish between private and social costs. The costs arising from greater capital usage by banks is of expressly private nature and affects only a few. Socially, it is expensive if banks have too little capital. In view of the above, with his co-authors, she suggested the prescription of multiple capital level already in 2010. Apart from Admati, other authors also argue for higher capital requirement. For example, HAgENDORfF and VALlascas recommend the prescription of double-digit capital adequacy, not on the basis of RWA, but on full asset basis instead. (CEPR Press (2015) point 2.2) In the same volume, RATnOvsKi suggests a leverage ratio of $9 \%$ and capital adequacy of $18 \%$ at the peak of economic growth (point 2.4 ).

49 BIS (2019)

50 CEPR Press (2015, point 2.1).

51 RGFS (2009) 
planned without integrating it with the liquidity measures taken by the central bank. The cheap provision of ex-post liquidity is acceptable only along the accurate planning of ex-ante rules. Based on his proposal, central banks, operating as "pawnbrokers" should provide loans for the banks to pay their due liabilities on condition that the banks give appropriate collateral and pay the compulsory insurance premium each year (actually the haircut applied to guarantees).52

According to D. K. Tarullo, the former Governor of FED in charge of supervision and regulation, the regulation of liquidity and funding may the most urgent macroprudential task. The Basel III banking liquidity regulation has problems, but the rules should not be abolished, but rather rectified. (The LCR may increase difficulties, as it encourages the banks to "store" liquidity in stress situations; the NSFR is unnecessarily restrictive, while it fails to solve liquidity problems in stress situations.) Basel III should be replaced by regulatory frameworks which consider the actual funding patterns of large banks; properly complement the rules on capital and the lender of last resort policies and protect banks from excessive reliance on short-term funding. The liquidity of banks principally depends on their clearing partners (Central Counterparties, insurance companies, different funds, etc.). In stress situations, non-banks pose funding risk and may carry potential systemic risk. Liquidity regulations have to force banks subject to prudential regulation to provide the liquidity of non-banks de facto..$^{53}$

Under stricter capital adequacy and liquidity rules, the banking sector is less capable of financing the real economy, which holds back GDP growth.

It is a perpetual topic for debate between the regulators and the sector whether stricter prudential rules restrict the lending ability of banks, and if they do, to what extent, and whether the benefits from the growth of financial stability exceed the possible negative impact.

The impact assessments conducted by the BCBS and the FSB with the involvement of professional organisations led to inconsistent findings regarding the judgement of the impact of the regulation on the real economy already prior to the introduction of the rules.

Based on the report issued by the Basel Committee on Banking Supervision in August 2010, the new regulation has definitely net economic benefits, as the se-

52 BIS (2019)

53 According to the author, liquidity regulation is the least completed area of post-crisis reforms, regarding both scientific research and politics, therefore it is a regulatory task that requires the most urgent solution. Practically, the relation between capital and liquidity regulation, the relation between liquidity regulation and the central bank's lender of last resort function, as well as its impact on financial intermediation, including access to secure assets, are unexplored (TARUllo, 2019). 
curity and stability of the global banking system is increasing, the likelihood of financial crises and that of the resulting losses is decreasing.54 The benefits of the new regulation definitely exceed the output costs arising from the stricter capital and liquidity requirements. Based on the estimations of the joint macroeconomic group of the FSB and the BCBS (MAG), the expected sacrifice of capital requirement increase in GDP decrease will be minimal.s5 If the higher requirements are introduced over a period of four and a half years, the group estimates that 1 percentage point capital increase entails $0.2 \%$ decrease in GDP during the entire introductory period, which means $0.04 \%$ decrease in the rate of growth on average. A $25 \%$ increase in the liquid asset demand has half of the effect of a 1 percentage point increase in capital requirement.

At the same time, the impact assessment conducted by the IIF in collaboration with the European Banking Federation indicated that the potential negative effects of the Basel III regulation were significantly higher. According to the report, the European GDP growth will be 4.4\% lower, while the increase in the number of jobs will be lower by almost 5 million jobs owing to the proposed regulatory package..$^{56}$

The different assessment of the consequences of the regulation has not changed since then. In the course of finalising the Basel III regulation, the sector was continuously emphasising the negative impact of further tightening on lending. In its communication prior to the announcement of the agreement in December 2017, The European Banking Federation drew attention to the fact that the new regulation threatens the financing of the European economy by punishing low-risk transactions (mainly residential property financing).

By contrast, according to the results of the cumulated quantitative impact assessment conducted by the BCBS based on data from the end of 2015, which were published upon the announcement of the agreement, the increase in capital requirement amounts to merely some tenths of a percentage point due to the Basel III rules..$^{57}$ The report acknowledges that the dispersion of the results by bank is high.

According to the latest assessment of the FSB, growth varies by region, but nothing shows that the reform would have led to lower credit supply.58

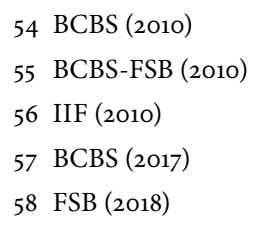


The analyses agree on one thing: the finalising of the Basel III rules has a graver than average effect on the European banking sector for several reasons. With this in mind, both the European Commission and the European Banking Federation emphasise that an impact assessment presenting the actual combined effects is required prior to the European introduction of the global rules adopted in December 2017.

The European Commission has been striving to implement the Basel III Accord by taking into account European features during transposition and preventing the regulation from restricting the lending ability of EU banks. On the other hand, the European Commission expressly intended to encourage lending to SMEs and the financing of infrastructure.

The stricter capital adequacy and liquidity rules considerably reduce the profitability of banks, therefore investment in the banking sector becomes less attractive. At the same time, meeting the requirements would need the involvement of more and more capital/external resources.

On the one hand, hopefully, consolidated capital and liquidity will reduce the likelihood of a future banking crisis, but the excessively stringent rules will decrease efficiency. The prescription of a higher capital level directly lowers return on equity (ROE), while the necessity of holding short-term assets with lower return and the performance of the NSFR also involve sacrifice regarding profitability. The situation is paradoxical in many respects: Due to the strict capital and liquidity requirements, the sector can be considered to be more stable than earlier, however, partly owing to the stringent rules, its profitability is not sufficient, which is a factor threatening stability in the long run..$^{59}$ Meanwhile, the regulation, including the resolution requirements, would need the involvement of more and more capital/external resources, but the lack of lucrativeness reduces the investors' interest. Due to capital conservation buffer rules, the generated income often cannot be distributed, which further decreases the attraction of investment in the sector.

Due to lower profit, banks have to find new ways of earning money, which drives the institutions towards taking higher risks. Financial innovations may weaken the stability of the system and lead to a new subprime crisis.

59 In the 2017 report of the SSM, Daniele Nouy, the first chairperson of the SSM, wrote that the biggest challenge the banks of the Eurozone face is low profitability. Some banks are not even able to produce capital costs, which is unsustainable in the long run. Unprofitable banks cause a problem even for the supervisory authorities, as they are not able to support economic growth and replenish capital buffer (ECB, 2017). 


\subsubsection{The solution of the TBTF problem could be the prevention and avoidance of a future crisis}

The tightening of microprudential rules and prioritising macroprudential regulatory aspects reduces the likelihood of the evolvement or deepening of a future crisis.

Whether crises are preventable is a highly controversial issue both at political and professional level. The authorities in charge of the regulation seriously believe that the regulation and system of institutions established after the crisis, which also reflects macroprudential approach, is able to preserve financial stability and avoid a financial crisis of the scale and depth of the one that occurred in 2008. Borio (2014) stresses that macroprudential regulation may be less able to restrict cyclical fluctuations, therefore the only realistic goal could be to increase resistance to cyclical risks.

By contrast, Admati (2019) believes that financial crises can be prevented by means of sufficiently strict regulation. She argues that one of the misleading narratives of financial crises is that they are similar to natural disasters, therefore they are unavoidable. This interpretation drives discussions towards preparation for the crisis. As if an ambulance was sent to the scene of an accident instead of prevention. The regulatory fault that led to the evolvement of the shadow banking system is used as an argument against strict regulation in a misleading manner.

Regulation is necessarily based on previous experience and aims to eliminate the harmful phenomena revealed and the consequences. At the same time, there is a consensus that the next crisis will be unexpected and unpredictable. Based on the above, the regulation established after the 2008 crisis could be able to alleviate the effect of the crisis indeed. At the same time, the competent authorities are continuously observing and monitoring the new/evolving risks. If it is reasonable, they will take the necessary, hopefully successful regulatory measures.

Although the macroprudential approach helps the identification and management of system-level risks, it should be understood that the macroprudential policies are still very new, therefore they are based on limited experience. According to Anne Le Lorier, a former first vice president of the central bank of France, the improvement of the set of instruments and institutional background of macroprudential policies is one of the most important tasks. ${ }^{60}$

It is doubtful whether the crisis management of bankrupt large banks works.

6o BIS (2019) 
The resolution of TBTF institutions is untested, and, some believe, seems to be unsolved.$^{61}$ Although the political intention to protect taxpayers' money is completely reasonable, regarding crisis management, it can cause a practical problem if the possibility of government bailout of banks is completely removed from the toolkit of the authorities. ${ }^{62}$

Tarullo (2019) also examined if the orderly resolution of large financial institutions affected by the crisis is a real option in practice. According to the author, in the case of an idiosyncratic crisis, this solution is imaginable. On the other hand, he thinks that it is unlikely that more crisis-stricken institution will be subject to resolution in a stress period. Due to the risks threatening the financial system, it is sure that other solutions would be look for to stabilise the situation, which means that the TBTF problem has remained unsolved. At the same time, in order to comply with the market principle, the former rights of the Fed and the FDIC have been cut back, therefore in the event of a future banking crisis, the two options will include the use of an inadequate toolkit and the exceedance of the authorisation by the Congress in the USA. According to Tarullo, as far as short-term funding is concerned, comprehensive regulation applying to the whole financial system would be required.

Avgouleas and Goodhart (2019) also doubt that in the event of a system-level crisis, the adopted regulation, including the conversion of pre-financed TLAC and MREL liabilities, would be an effective solution for the avoidance of the bailout of G-SIB banks. It is also uncertain whether bail-in has any undesired effects in the case of non-individual, but system-level crises. Finally, it is not clear either how effective resolution regimes are in decreasing moral hazard without the expost punishment system of bank executives. ${ }^{63}$ The authors also emphasise that the normative values related to resolution are unclear, overlap and in some cases contradict the aims of current resolution frameworks. In addition to this, they

61 The above view is held by e.g. Lagarde and Herring (MiLls, 2018), as well as Le Lorier (BIS, 2019).

62 Pursuant to the Dodd-Frank Act, bail-out is illegal in the USA. The government bailout of banks would require the modification of the law, which may significantly reduce the efficiency of crisis management.

Herring emphasises that crisis management will be much harder for the authorities because of the Dodd-Frank reforms, while the new crisis prevention and resolution measures might prove to be inappropriate. (MiLls, 2018)

63 Le Lorier also mentions that the question of the responsibility of the management of bankrupt institutions is still unsolved and the elaboration of appropriate incentives and sanctions is required (BIS, 2019).

In general, in the professional literature examining the consequences of the crisis, the punishment of guilty bankers for their activity is a recurrent issue. After the crisis, the lack of impeachment and the fact that income differences did not decrease even as a result of the crisis may have largely contributed to the outbreak of political populism. 
refer to the consequences of the overly draconian bail-in regime and the moral hazards posed; in order to avoid forced sales, they argue for a more flexible liquidity supply system.

The performance of the Basel III liquidity indicators was not linked to the central guaranteeing of liquidity required in a crisis situation. Inappropriately providing liquidity during resolution may be an obstacle to successful resolution; having access to liquidity may have a contagion effect. ${ }^{64}$ Only central banks could provide liquidity during resolution, holding the collaterals collected from the banks.

In connection with cross-border resolutions, serious concerns were raised regarding the compliance and efficiency of the cooperation between authorities.

Meeting the TLAC and MREL requirements is particularly burdensome for the banks, while bail-inable instruments are less attractive for investors. The issue of bail-inable bonds entails extra costs, the possible motivations of investors in bonds are unclear/contradictory; it is not even sure whether there is/will be sufficient demand for bonds. ${ }^{65}$

Related to the fundraising, another problem in the EU is that the cost of funds is different in each jurisdiction (even within the banking union), which violates the principle of single market and level playing field.

In addition to effective crisis management, the proposals on the solution of the TBTF problem aimed to decrease the size of banks and define their activities. On the other hand, the sizes of the institutions have become larger than prior to the crisis due to different mergers, and the concentration of the sector has continued. ${ }^{66}$

64 Andrea Enria, the new Chairperson of the SSM, mentioned the lack of agreements on the provision of liquidity as one of the obstacles to resolution (ECB, 2018).

According to Avgouleas and Goodhart (2019), the fact that in the UK, the Bank of England provides liquidity required during resolution under the guarantee of the Exchequer is a praiseworthy solution. The USA, and recently the European Union, as well, decided not to grant this right to the central bank. In the USA, the Department of the Treasury, while in the EU, the ESM are entitled to provide loans, which are more difficult to get access to. The authors believe that within the Banking Union, the ECB should be authorised to provide liquidity under resolution, with certain guarantees.

65 The recent BIS monitoring (supposing the complete introduction of the rules) revealed a TLAC instrument deficit of EUR 108.8 billion in G-SIB banks.

66 If JPMorgan Chase were a country, it would be the 8th biggest economy of the world, it would be bigger than Brazil, Canada or Russia (ANDERs, 2018). 


\subsubsection{The set of rules in the light of preliminary expectations}

\section{The regulation is too complex and unreasonably expensive.}

Even regulatory authorities do not deny that the set of rules established after the crisis is complex. The debate is rather about whether the system needs to be complex and the compliance costs are reasonable (if they return at least at public level). ${ }^{67}$

Some critics believe that the application of some simple, correctly calibrated, measurable and easily controllable rules could be a real alternative. Based on her very critical opinion, Admati (2019) believes that simple and cost-effective regulation would do away with wrong incentives. Instead of this, as if the regulatory authorities had taken a real action, the authorities established an extremely complex set of rules, which has more costs than advantages. The rules according to which the financial system operates are not adequate and, in some cases, they are even counterproductive. Security would require a much higher capital level. The regulatory authorities use stress tests to reassure themselves and the public that the banks are sufficiently secure. However, stress tests based on strong assumptions are not able to predict the market dynamics of the interconnected system in the event of an actual unexpected crisis, therefore they provide only false security. It is probably an illusion that some simple rules could be enough to appropriately regulate the complicated and divergent financial system. A certain level of complexity in regulation is unavoidable. At the same time, current regulation is so complicated and complex that it is not or hardly transparent as a whole. The interactions between different rules are still unexplored. Despite emphasising the holistic approach, they have not really been examined so far. It is a similar situation to when upon the advice of several doctors, someone starts taking different kinds of medicine for various illnesses, but no one can predict the possible result. Although the Basel Committee on Banking Supervision committed itself to establishing a balance between the simple/transparent and the risk-sensitive regulation, the result is neither simple, nor transparent and is less sensitive to risks than the previous regulation. ${ }^{68}$

67 Two additional facts to describe the compliance burden: SIRONI (2018) estimates that a mediumsized bank needs to have 200 full-time employees to comply with the rules. In Europe, the balance sheet total of 350 banks exceeds EUR 1 billion, therefore compliance with the rules would require around 70000 new employees at EU level.

According to Mervyn King, the system is so complicated that the compliance and legal departments will play a crucial role in private financial institutions (BIS, 2019).

68 According to Mérö (2018), the finalised Basel III can be regarded as an element of transition towards less risk-sensitive regulation. Her other important statement is that "The underlying in- 
It is a legitimate expectation that in the future, regulatory authorities should devote more attention to the examination of interactions between rules and take decisive steps towards the simplification of certain rules.

Irrespective of criticising excessive complexity, it is a general phenomenon that we tend to forget our earlier experience as we are leaving behind the crisis in time. The following argument comes up again: excessively strict rules slow down lending/growth, while lobbying for the relaxation of rules is intensifying. ${ }^{69}$

Strict and excessively complex regulation strengthens shadow banking activity. The non-regulation of financial innovations is presumably inevitable, but it poses systemic risk.

"Overregulation" of the banking sector drives towards non-regulated shadow banking activity $7^{\circ}$ Post-crisis regulation intended to tackle this problem by regulating the shadow banking system. With moderate success, to say the least. In spite of the fact that it has been laid down in the principles for a long time that instead of institutions, activities shall be regulate, there are only limited results in this field, which raises serious problems regarding level playing field. As regards BigTech and FinTech companies, the consequences are unpredictable; the nonregulation of their activity may be the most important systemic risk factor. $A$ future crisis might derive from non-banking financial intermediation. The risks are outside the strictly regulated banking sector.

Of course, the future is unknown. Innovations are ahead of existing rules, but it can cause a serious problem is new regulation is adopted too late and cannot keep up with too fast innovation..$^{11}$ Andres (2018) thinks that it was not deregulation,

centive structures cannot be seen in a complicated bank regulation system that is difficult to follow, therefore they might have unexpected/unintended side effects in the future."

69 For example, see: Andres (2018) or Lagarde (MILls, 2018). About the relaxation of regulation in the USA, see: TARUllo (2019).

70 About the non-regulation of shadow banking activity see BAER (2019) or TARULLO (2019), as well. According to Herring, as a result of the regulatory reform, the risk has been only transferred to other institutions and markets which are less under scrutiny and are practically non-regulated (Mills, 2018).

71 According to DӧмӧтӧR et al (2016): “The current banking sector - inter alia owing to the immatureness of the stock market - is still not suitable for giving innovation-based growth a boost. As a result, the role of financing is being taken over by other, non-financial institutions. Peer-to-peer lending and, based on the model of social media, community funding is evolving. The new participants play an important role in the promotion of financial innovation, which could be key to reform and further growth. However, this poses threats, as well, because actually, the recent crisis was triggered by a kind of financial innovation. Based on the above, regulation, especially the restrictions on regulation, should be continuously reformed, following changes in the financial system. Namely, the biggest danger of the aforementioned funding forms is that despite carrying risks similar to traditional bank financing, different restrictions apply to them. As a result, agreements which are 
but rather non-regulated new activities and instruments which led to the crisis in the 1990 and 2000 .

Fast-paced digitalisation is a challenge to the business models of banks, while cyber risk is increasing. ${ }^{72}$ Companies suffer from cyberattacks on a daily basis, but official regulation is lagging behind the events in this field, as well, it does not protect the companies against cyber incidents.

\section{In practice, the global character of regulation has been damaged}

After the crisis, there was almost complete agreement that due to the global character of the banking system and the financial crisis, the response given to the crisis should be global, as well. This endeavour was justified by aspects of neutral competition as well as by the restriction of the possibility of regulatory arbitrage. Regarding issue, there was a consensus at the level of global politics, as well, therefore, under the guidance of the G2O, the BCBS and the FSB could start elaborating the specific elements of the regulatory reform.

Although global authorities have been clearly and explicitly striving to consistently introduce the adopted rules in different jurisdictions from the beginning, in reality, have not managed to achieve this fully. In the USA, the introduction of the Dodd-Frank Act in 2010 preceded the adoption of the Basel III regulation, therefore the harmonisation of the two regulations was difficult. ${ }^{73}$ The EU and the US regulations are also different regarding their philosophy, as in the USA, internationally adopted rules are applied only to a circle of institutions exceeding a certain size, while in the European Union, they are applied to all credit institutions and investment firms. ${ }^{74,75}$

more favourable for both the creditors and the investors can be reached, representing a kind of regulatory arbitrage. However, this situation carries system-level risks which characterised the situation of the financial sector in 2007 , before the crisis.” (p. 542)

72 Based on the survey of Grant Thorton - MIT GCFP (2017), cybersecurity is the only field where banking risk management has exceeded regulatory expectations.

73 For further details on this, see: Hoshi in the CEPR Press Studies 3.5 (DANIElsson, 2015).

74 TARUllo (2019) argues for the tiering of the regulation. In the USA, certain stricter regulations applied only to banks with assets over USD 50 billion (e.g. more stringent capital requirements, liquidity rules, risk management requirements, stress tests or the Volcker Rule.) The financial regulation of 2018 raised this limit to USD 250 billion, which is perhaps exaggerated, but the approach should be appreciated. These measures facilitate the better allocation and more efficient use of risk management and supervisory capacities.

75 Biedermann-Orosz (2015) give a detailed description of the differences between the US and the EU regulations, paying special attention to the regulation of compensation systems, capital requirements, derivatives, credit rating agencies, the supervision of hedge funds and consumer protection. In spite of the fact that the Financial Markets Regulatory Dialogue between the USA and the EU has been effective since 2002, the differences are striking. MiLls (2018) also deals with the reasons for the faster and more convincing recovery of the USA. 
Due to the application of the European Single Rule Book, smaller authorities try to lessen the disproportionately high regulatory/compliance burden on small institutions by applying the principle of proportionality, however, their efforts have not been very successful so far. ${ }^{76}$ On the other hand, the large number of national/official options and discretions of the capital requirements regulation, which the European Central Bank is consistently striving to abolish, make uniform application fairly difficult.

In the course of the establishment of the Banking Union, an additional problem was that banking laws were only partly harmonised. The application of the macroprudential toolkit (e.g. LTV, LTI, systemic risk reserves), the bankruptcy law and the company law remained within national competence. Furthermore, a part of the supervisory toolkit and administrative sanctions did not harmonise. ${ }^{77}$

Non-identical regulation not only increases the possibility of regulatory arbitrage, but it also significantly increases the compliance costs of the institutions. Adherence to and the harmonisation of different sets of rules require a fairly large amount of time and money. The mutual recognition of each other's rules might be a practical solution to the problems arising from different rules. ${ }^{78}$

According to others, the global "one size fits all" approach is wrong. The customised nature of regulation and the discretional powers conferred on the authority improve efficiency, thus strengthening financial stability. ${ }^{79}$ In principle, regulation focusing on G-SIB banks does not exclude the application of more customised regulation to other institutions.

\section{The use of buffers considerably decreased the procyclical character of regula- tion. ${ }^{80}$}

After the crisis, the authorities prescribed the application of different buffers. If such buffers are never used, they become unnecessary burden regarding banking activity and economic growth. According to Baer (2019), when prescribing

76 Among the few results, we could mention that in the framework of the risk-reducing package adopted in November 2016, under the slogan of reinforcing proportionate application, reporting and publication requirements were decreased at smaller banks, the capital requirement calculation of trading positions was simplified and compensation rules were lessened.

77 Deslandes et al. (2019)

78 In its recently published Communiqué, the European Commission explained how the financial regulation of third countries is recognised as equivalent (EC, 2019).

79 According to LAeven and Levine (DAnielsson, 2015, point 3.4), in order to enforce correct incentives, regulation should be adjusted to the existing financial management system and the ownership structure of banks.

80 In an interesting article, one of the publicists of the Financial Times wrote that regulation is necessarily procyclical for economic, ideological, political and mainly human reasons (WoLF, 2019). 
buffers, regulators suppose that in the case of a crisis, banks spend their reserves and can continue lending, market making and other activities supporting the economy by fulfilling the minimum capital requirements. This assumption is the starting point of post-crisis capital and liquidity regulation. However, market participants do not behave in this way. Banks do not let their capital adequacy and liquidity decrease, they rather reduce their balance sheet total. Banks are not interested in reducing capital conservation buffer. Actually, buffer only increases capital level.

On the other hand, if they once introduce it, authorities are not willing to resort to the tool of reducing countercyclical buffer either, as during a crisis, decreasing the capital requirement prescribed for banks is a politically unpopular decision. The author believes that the assumption related to buffers is a misconception in reality. At the same time, the facts that stricter requirements are prescribed for banks than earlier, while there are practically no requirements for non-banks operating in a similar market, jointly strengthen procyclicality. In the event of a crisis, the activity of non-bank intermediaries drops more drastically than that of banks.

Sironi (2018) criticises countercyclical capital buffer, because its use does not depend on the individual behaviour of the bank. Prudent banks are also punished for the aggressive expansion of other banks. Its application depends on the nationality of the borrower (in fact, on the place of landing and not that of the bank), while this requirement seeks to control excessive lending. Moreover, this rule can be easily circumvented if the loan is provided for an affiliate based in a country where no countercyclical buffer requirement exists. The losers of the regulation are SMEs operating in the country applying the buffer, as they cannot take out a loan from other countries.

Nor is the application of the countercyclical buffer supported by the negative correlation between the loan/GDP gap and the GDP growth.

\section{Initiatives for self-regulation become marginalised.}

In the period following the subprime crisis, it was laid down as a principle that, if possible, market self-regulatory solutions had to be prioritised; the sector should be given an opportunity to develop the tools by means of which risks arising in the system can be mitigated. ${ }^{81}$ Already in the initial period, there were market self-regulatory attempts (e.g. by the credit rating agencies), but these initiatives were marginalised soon. Simultaneously, among other things, the enforcement of the interest of banks was also restricted by imposing significant limits on mod-

81 Móra (2008) 
el use within administrative regulation. ${ }^{82}$ By now, the conclusion drawn by the Hungarian author trio in 2011 has become a generally accepted view: "New rules can only be forced on the financial system, self-regulation of appropriate direction and scale is a mere illusion." ${ }^{3}$

Nonetheless, the adoption of the rules takes more time both at global and European level, in the framework of an appropriate consultation process (in the case of more important rules, a multiple-stage process), providing a theoretical and, in several cases, a real opportunity for the banks to enforce their interests at least partially.

\section{The market discipline is expected to be stronger than before.}

The third pillar, the enforcement of market discipline by providing information for the public, was an important new element of the Basel II regulation. The regulators supposed that based on the compulsorily disclosed extra information on the solvency capital, capital adequacy, risk management of institutions, market participants distinguished riskier banks from less risky banks. By increasing the funding costs of riskier banks, they wanted to encourage them to reduce risktaking. As opposed to this, the series of government bail-out of banks during the crisis seriously violated the market principle. If large banks are bailed out, nothing encourages the monitoring of banking information.

The introduction of the bail-in mechanism, the TLAC and MREL requirements, even due to the investors in such instruments, undoubtedly contributes to the enforcement of market discipline and limits excessive risk-taking.

In January 2015 and in March 2017, the BCBS significantly extended the circle of information that had to be published in accordance with the third pillar..$^{84,85}$ The revised third pillar publication requirements published in December 2018 already include the finalised Basel III regulations adopted in December 2017 and are amended with other information (publication requirements related to pledged

82 MÉRŐ (2018)

83 BÁNFi-KüRTHY-BÁNFi (2011)

84 The standard allowed the better comparison of the information published by banks on riskweighted assets (RW).

85 The consolidated and reinforced 3 rd pillar disclosure frameworks included all the requirements (requirements on capital, the leverage ratio, liquidity indicators, G-SIBs indicators, countercyclical capital buffer, the interest rate risk of the banking-book and compensation) adopted earlier. In addition, they introduced the indicator system of the banks' basic prudential indexes (dashboard) and collected the new publication requirements describing prudential assessment adjustments. 
assets, the distribution of capital, the prudential management of problematic assets), as well. ${ }^{86}$

The consolidated publication requirements undoubtedly strengthen the foundation of the decisions taken by market participants, however, banks often call into question whether stakeholders are able to properly assess the published information.

To conclude my article, I cite that the European Banking Federation set the following goal for the EU to achieve in the 2019-2024 legislative period under the title "Achieve a Stable and Efficient Regulatory Framework":

"An assessment of the current regulatory framework, overlap, interlinkage and interconnections

Following the decade-long implementation of a continuous programme of regulatory change in the wake of the 2008 financial crisis, we now believe the time has come to take stock and evaluate what is and what is not working, and to make further adjustments where necessary. A stable and efficient regulatory framework is crucial for banks.

A more efficient system of financial regulation is a critical pillar in the policies to stimulate growth. This should help remove unnecessary burdens, increase banks' profitability, within the European banking system, without reducing the high level of resilience achieved.

In the same spirit of the Financial Stability Board (FSB), which is currently evaluating the G2o reforms, rather than triggering additional reforms, the European Union actions should be equally aligned. They should scrutinise existing requirements in the context of an analysis of potential efficiency gains.

The volume and complexity of regulations affecting the banking system are enormous. The Capital Requirements Regulation and Directive are so intricate that it becomes complex for banks to manage its implementation, and, challenging to be fully compliant. In addition, banks dedicate significant amounts of resources in order to comply with the long list of other regulations and requirements, starting from sector-specific ones such as European Market Infrastructure Regulation (EMIR), Banking Recovery and Resolution Directive (BRRD), Market Abuse Directive (MAD), Markets in Financial Instruments Directive (MiFID), Prospectus, the legal framework for payment services (such as Payment Services Directive 2) and right through to cross-sectoral ones like the General Data Protection Regulation (GDPR). 
At the same time, and in order to maintain the stability of financial system, the integration of Anti-Money Laundering considerations into the supervisory framework should also be seriously contemplated. It has become apparent that AML/CFT issues can quickly become major prudential issues affecting the banking sector's stability (e.g. related sanctions). In a more harmonised, and hence, simplified regulatory environment, a good part of resources currently employed in this area could be diverted to banking activities supporting and driving the real economy.

We believe that the new European Commission should now analyse together with the banking sector whether there are opportunities for efficiency, streamlining and simplifying regulation along the better regulation principles. We believe that substantial efficiency gains may arise, if a critical review of the banking regulatory framework is carried out. The review should be complemented by an in-depth examination regarding a level playing field with non-bank competitors to ensure all activities in the financial sector are regulated the same way." ${ }^{87}$ I am convinced that the coordination and simplification of regulation, as well as the assurance of its level playing field character, with special regard to non-bank financial intermediaries, are fundamental interests not only of the banking sector, but of the wider community, as well. Fortunately, the decision-makers of the European Union have recognised this demand. However, regarding actual revision of the regulation, no considerable progress has been made so far. ${ }^{88}$

$87 \operatorname{EBF}(2019$, pp. 32-33)

88 The European Commission announced its Regulatory Fitness and Performance Programme (REFIT) already in 2012. The programme, which aims to realise more effective and less expensive regulation, is general character and goes far beyond financial regulation. In 2015, a REFIT platform consisting of the representatives of the authorities of the member states and other stakeholders (mainly the representatives or civil organisations) was set up, as well. The Commission going out in 2019 made 150 proposals on the simplification of regulation during its 5-year term in office. The Communiqué of the Commission published in October 2018, emphasised the better implementation of the principles of subsidiarity and proportionality, In the second half of 2018, they consulted on the principles of Better Regulation. The result of the consultation was published in March. 


\section{REFERENCES}

Admati, A. R. (2019): Towards a Better Financial System. Econfip Research Brief, January.

Andres, T. (2018): How the financial crisis changed banking. Divided Decade, 21 December.

Avgouleas, E. - Goodhart, C. (2019): Bank Resolution 10 Years from the Global Financial Crises A Systemic Reappraisal. School of European Political Economy, Working Paper 7.

BÁвоsıк MÁria (2015): Együtt vagy külön? Mely tevékenységeket végezhetik a betétgyüjtő bankok és melyeket nem? - Szerkezeti átalakítás a bankszektorban [Together or Separately? Which activities can deposit-taking banks carry out and which cannot? - Structural reorganisation in the banking sector]. Privátbankár, 7 April.

Batr, G. (2019): The Next Financial Crisis and the Great Buffer Fallacy - Has the enhanced resilience and resolvability of large banks reduced the likelihood of another financial crisis or increased it? Bank Policy Institute, Banking Perspectives, 12 March.

BÁNFi TAMÁs - KÜRThy GÁBOR - BÁNFi AtTila (2011): Szabályozás a pénzügyi válság(ok) után (között): kényszer és lehetőség [Regulation after (between) financial crises]. Pénzügyi Szemle 56(2).

BCBS (2010): An assessment of the long-term economic impact of stronger capital and liquidity requirements. August.

BCBS (2013): The Regulatory Framework: balancing risk-sensitivity, simplicity and comparability, Discussion Paper, 8 July.

BCBS (2017): Basel III Monitoring Report - Results of the cumulative quantitative impact study. 7 December.

BCBS-FSB (2010): Macroeconomic Assessment Group: Assessing the macroeconomic impact of the transition to stronger capital and liquidity requirements - Interim Report. August.

Biedermann ZsuzsánNA - Orosz ÁGnes (2015): Eltérő irányú szabályozások a válság után? Az EU és az Egyesült Államok válaszainak összevetése. [The comparison of responses given in the EU and in the USA]. Hitelintézeti Szemle 14(1), March.

BIS (2019a): Ten years after the Great Financial Crisis: what has changed? Papers No 103, June.

BIS (2019b): The costs and benefits of bank capital - a review of the literature. Working Paper No 37, June.

Borio, C. (2014): Macroprudential frameworks: (Too) great expectations? In SCHOENMAKER, D. (ed.) (2014): Macroprudentialism. A VoxEU.org Book, Duisenberg: CEPR Press.

Borio, C. (2003): Towards a macruprudential framework for financial supervision and regulation? BIS Working Paper, No. 128.

CGFS (2018): Committee on the Global Danielsson Financial System Structural changes in banking after the crisis, 24 January.

Danielsson, J. (ed.) (2015): Post-Crisis Banking Regulation, Evaluation of economic thinking as it happened on Vox. A VoxEU.org Book, Duisenberg: CEPR Press.

Deslandes, J. -Dias, C. -Magnus, M. (2019): Banking Union: Completing the Single Rule Book. European Parliament Briefing, July.

DöMÖTÖr ERIKA - MÁTYÁs LÁszló - BALÁzsI LÁszLó (2016): Gazdasági növekedés, válság és sZabályozás. Összegzés a COEURE-projekt tanulmányaiból II. [Economic growth, crisis and regulation A summary of the studies of the COEURE project), II]. Közgazdasági Szemle 63(5), május, 524-547.

EBF (2019): Manifesto: Boosting Europe - EBF recommendations for the 2019-2024 legislative policy cycle and beyond. May. 
EC (2019): Equivalence in the area of financial services, Communication from the Commission to the European Parliament, the Council, the European Central Bank, the European Economic and Social Committee and the Committee of the Regions 29.07.2019 COM(2019) 349 final.

ECB (2017): Annual Report on supervisory activities 2017.

ECB (2018): Annual Report on supervisory activities 2018.

FSB (2018): Implementation and Effects of the G2o Financial Regulatory Reforms: Fourth Annual Report. 28 November.

Gambacorta, L. - Van Rixtel, A. (2013): Structural bank regulation initiatives: approaches and implications. BIS Working Papers No 412, April.

Grant Thorton - MIT GCFP (2017): The risk management function of the future - How regulatory mandates and expectations are shaping risk management at US: banks 2017. Survey results.

IIF (2010): Interim Report on the Cumulative Impact on the Global Economy of Proposed Changes in the Banking Regulatory Framework. June.

MilLs, E. E. - JD, MBA, CFA (2018): A Decade After the Great Recession, Is the Global Financial System Safer? Wharton School, University of Pennsylvania, Knowledge@Wharton, 11 September.

MÉRŐ KATALIN (2011): A bankszabályozás kihívásai és változásai a pénzügyi-gazdasági válság hatására [The challenges and changes of bank regulation under the influence of the financial and economic crisis]. Verseny és szabályozás $5(1)$.

MÉRő Katalin (2017): A makroprudenciális szabályozás térnyerése - Hogyan változtatta meg a globális pénzügyi válság a bankszabályozást? [The spread of macroprudential regulation How has the global financial crisis changed bank regulation?] In: Kálmán János (ed.) (2017): Állam - Válság - Pénzügyek [State - Crisis - Finances], Budapest, Gondolat.

MÉRő KATALIN (2008): A kockázatalapú bankszabályozás előretörése és visszaszorulása - az ösztönzési struktúrák szerepe [The increase and decrease in risk-based bank regulation - the role of incentive structures]. Közgazdasági Szemle 65(10), October, 981-1005.

Móra MÁria (2008): Mi a teendő? Kiútkeresés a másodrendủ jelzálogpiaci válság nyomán [What Should Be Done? Finding the way out from the sub-prime mortgage market crisis]. Hitelintézeti Szemle 7(5), 520-539.

Oxenford. M. (2018): The Lasting Effects of the Financial Crisis Have Yet to Be Felt. Chatham House, 12 January.

Pesuth TAMÁs (2016): Bankszabályozási változások a válság után - A banki kultúra térnyerése [Changes in bank regulation after the crisis - The expansion of banking culture]. Köz-Gazdaság 11(1), 113-129.

RGFS (2009): Post-Financial Crisis Regulatory Reform Proposals From Global „One-Size-Fits-All” to Locally - Specific Regulation. Research Group on the Financial System, https://www.zenginkyo.or.jp/fileadmin/res/abstract/affiliate/kintyo/kintyo_2009_1_2.pdf.

Sironi, A. (2018): The evolution of banking regulation since the financial crises: a critical assessment. Bocconi Working Paper No 103, December.

Tarullo, D. K. (2019): Financial Regulation: Still Unsettled a Decade After the Crisis. Journal of Economic Perspectives 33(1), Winter.

Viñals, J. - Pazarbasioglu, C. - Surti, J. - Narain, A. - Erbenova, M. - Chow, J. (2013): Creating a Safer Financial System: Will the Volcker, Vickers, and Liikanen Structural Measures Help? IMF Staff Discussion Note, May.

Wolf, M. (2019): Why further financial crises inevitable. Financial Times, 19 March. 